\title{
Pengelolaan Penyakit Tanaman Terpadu
}

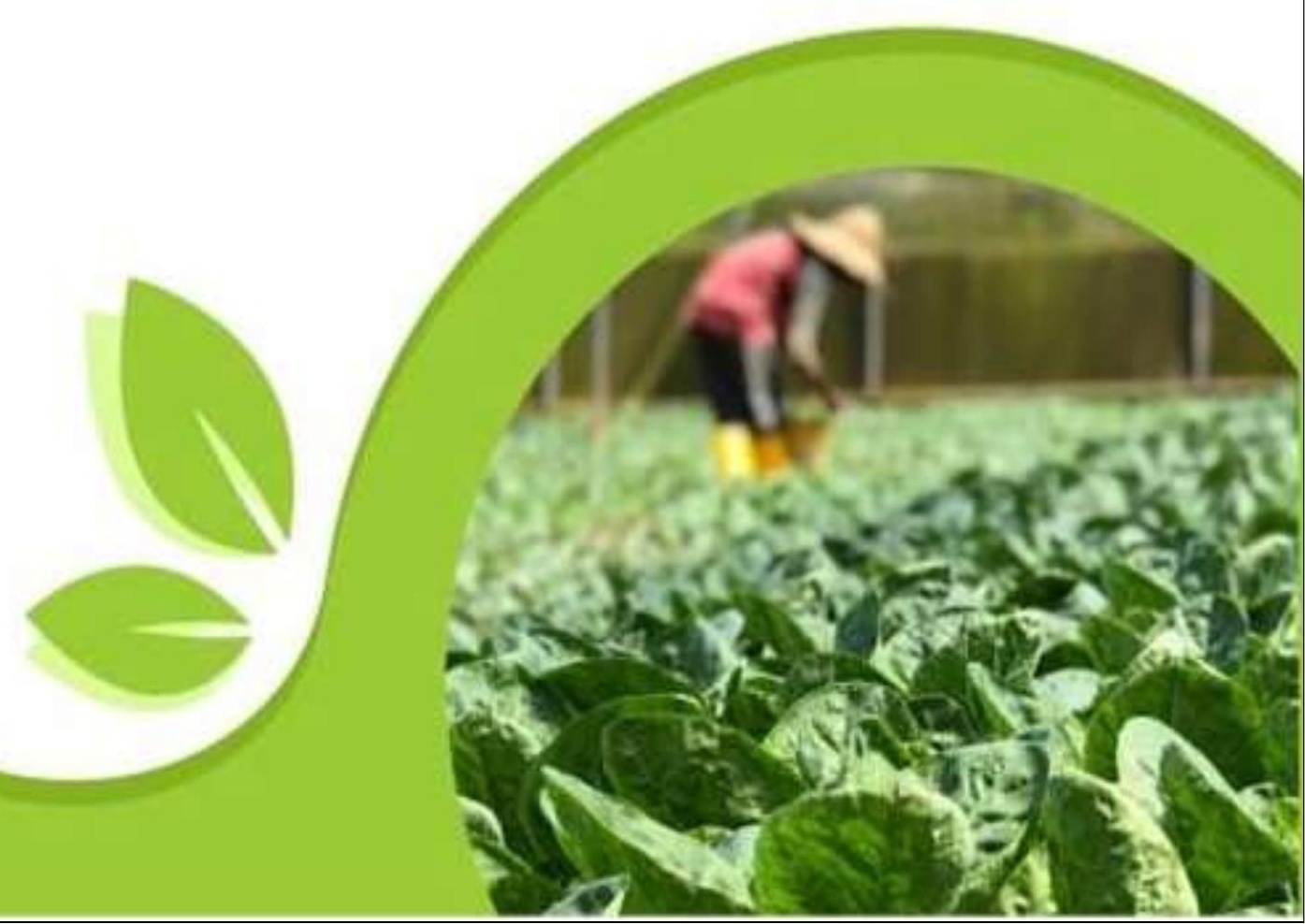




\title{
PENGELOLAAN PENYAKIT TANAMAN TERPADU
}

\author{
Oleh \\ Sutarman \\ Andriani E Prihatiningrum \\ A Miftakhurrohmat
}

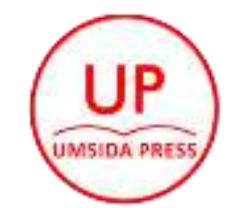

UMSIDA PRESS

Diterbitkan oleh UMSIDA PRESS

Jl. Mojopahit 666 B Sidoarjo

ISBN: 978-623-6833-08-7

Copyright $(2020$

Sutarman

All rights reserved

Hak cipta dilindungi undang-undang.

Dilarang memperbanyak atau memindahkan sebagian atau seluruh isi buku ini ke dalam bentuk apapun, secara elektronis, maupun mekanis, termasuk fotokopi, merekam, atau dengan teknik perekaman lainnya, tanpa izin tertulis dari penerbit.

[Berdasarkan UU No. 19 Tahun 2000 tentang Hak Cipta Bab XII Ketentuan Pidana, Pasal 27, Ayat (1), (2), dan (6) 


\section{PENGELOLAAN PENYAKIT TANAMAN TERPADU}

Penyusun

Sutarman

Dosen Program Studi Agroteknologi

Fakultas Sains dan Teknologi

Universitas Muhammadiyah Sidoarjo

Editor ahli

Prof. Dr. Ir. Dyah Roeswitawati, MS

Editor

Dyah Satiti

Penerbit

UMSIDA PRESS

P3I Universitas Muhammadiyah Sidoarjo

Kampus 1 Universitas Muhamamdiyah Sidoarjo

Jl. Mojopahit 666 B Sidoarjo, Jawa Timur, Indonesia

Telp. +62 318945444

Fax +62 318949333

https://p3i.umsida.ac.id 


\section{KATA PENGANTAR}

Puji syukur kehadirat Allah SWT atas tersusunnya buku ajar dengan judul: "Pengelolan Penyakit Tanaman Hortikultur Terpadu" yang merupakan salah satu luaran penelitian sesuai kompetensi penyusun di bidang kesehatan dan penyakit tanaman serta agroteknologi.

Buku ini disusun berdasarkan hasil penelitian dan kajian literatur yang bersumber pada berbagai artikel jurnal Internasional relevan terkait dan jurnal yang khusus memuat tema penyakit tanaman yaitu Jurnal Hama dan Penyakit Tanaman Tropika yang mulai tahun 2018 semua artikelnya menggunakan bahasa Inggris.

Buku ini memuat sebagian materi perkuliahan Pengelolaan Hama dan Penyakit Tanaman Terpadu (PHPT). Di samping itu buku ini juga dapat digunakan bagi mahasiswa dan praktisi pertanian yang menggeluti persoalan kesehatan dan perlindungan tanman. Meskipun syarat mengambil mata kuliah PHPT ini mahasiswa harus lulus mata kuliah Dasar-dasar Perlindungan Tanaman, namun materi buku bisa dicerna dan dipahami mengingat materi disampaikan dengan ilustrasi yang memperjelas uraian. Oleh karenanya disarankan sambil membaca buku ini, pembaca dapat menggali ilmu-ilmu dasar penyakit tanaman dari berbagai sumber lainnya.

Pada kesempatan ini penulis menyampaikan terima kasih kepada: Rektor Universitas Muhammadiyah Sidoarjo (UMSIDA), Dekan, Ketua Program Studi Agroteknologi Fakultas Sains dan teknologi UMSIDA atas dukungan moril dan fasilitas yang disediakan bagi kelancaran penelitian dan penyusunan buku ini.

Semoga karya ilmiah ini bermanfaat.

Sidoarjo, Nopember 2020

Penyusun 


\section{DAFTAR ISI}

Halaman

KATA PENGANTAR ....................................... iv

DAFTAR ISI ….......................................... v

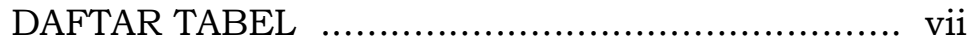

DAFTAR GAMBAR ....................................... viii

DAFTAR LAMPIRAN ...................................... ix

I. PENDAHULUAN [.......................................... 1

1.1 Latar Belakang........................................ 1

1.2 Standard Kompetensi.................................... 3

1.3 Lingkup dan Batasan............................... 6

II. EKOLOGI PENGELOLAAN PENYAKIT................... 10

2.1 Ekologi Penyakit.......................................10

2.2 Pengelolaan Agroekosistem ….................... 15

III. EPIDEMIOLOGI DAN PERAMALAN PENYAKIT .....22

3.1 Epidemiologi ......................................23

3.2 Teknik Penyusunan Model Epidemi................31

3.2 Peramalan Penyakit..................................38

IV. MUSUH ALAMI. ............................................. 41

4.1 Jenis-jenis Agensi Hayati ....................... 41

4.1.1 Jamur...................................... 42

4.1.2 Bakteri........................................ 44

4.1.3 Organisme lain............................ 46

4.2 Pemanfaatan dan formulasi...................... 47

4.3 Aplikasi agensia hayati........................... 54

V. TEKNIK PENGAMATAN PENYAKIT..................... 59

5.1 Pengamatan Gejala Peyakit...................... 59

5.2 Teknik Pengambilan Sampel.................... 62

5.3 Teknik Penilaian Intesitas Sampel............. 66

5.4 Pemanfaatan Data Hasil Pengamatan......... 73

5.5 Determinasi Patogen ............................ 76 
VI. PRINSIP DAN PENYUSUNAN PROGRAM PENGELOLAAN PENYAKIT........................... 80

6.1 Prinsip-prinsip Pegelolaan Penyakit.......... 82

6.2 Srategi Pegendalian Peyakit.................... 85

6.3 Konservasi Agroekosistem..................... 86

6.4 Integrasi Metode Pegendalian................. 89

6.5 Perancangan Program Pengelolaan Penyakit 94 6.5.1 Pembuatan rencana program......... .94

6.5.2 Monitoring dan evaluasi.................. 98

VII. APLIKASI PENGELOLAN PENYAKIT................ 101

7.1 Pengelolaan Penyakit Tanaman Pangan-Horti102

7.2 Pengelolaan Penyakit Tanaman Perkebunan 107

7.3Pengelolaan Pascapanen dan Penyimpanan 113

DAFTAR PUSTAKA............................................. 121 


\section{BAB 1 \\ PENDAHULUAN}

\subsection{Latar Belakang}

Dalam praktek budidaya pertanian dan usaha lain yang memanfaatkan tumbuhan untuk proses produksi baik pangan maupun non pangan selalu diganggu dan dihambat oleh orgaisme yang disebut sebagai patogen penyebab penyakit tanaman atau tumbuhan yang ditanam.

Sejak revolusi Industri hingga saat ini pengandalan pada daya bunuh dan daya hambat senyawa kimia sintetis toksik cenderung meningkat dari waktu ke waktu sejalan dengan pola peningkatan kebutuhan pangan dunia [1], meskipun selektif dalam penggunaan bahan aktifnya. Di lain pihak tuntutan kebutuhan pangan dan kebutuhan produk yang memanfaatkan vegetasi semakin meningkat.

Para ahli dan pemerhati pertanian dan lingkungan sudah memahami kecenderungan yang kurang menguntungkan tersebut. Berbagai riset untuk mencari alternatif pestisida kimia berbahaya terus ditumbuhkembangkan. Namun membutuhkan waktu yang panjang untuk memperbaiki keadaan. Sementara itu jauh lebih banyak individu-individu maupun kelompok dari pihak-pihak pemangku kepentingan belum menyadari begitu pentingnya pemahaman tentang 
integrated pest management (IPM) dalam kehidupan sehari-hari.

Oleh karena itu fokus perhatian pada sosialisasi kemajuan hasil riset dan teknologi yang agak mendalam dan mengarah pada implementasi IPM diarahkan pada kelompok pembelajar yaitu mahasiswa dan generasi muda pemerhati pertanian sebagai kader pengawal dan pelaksana implementasi IPM di dalam masyarakat nantinya.

Buku Pengelolaan Penyakit Tanaman Terpadu ini merupakan bagian dari alat pencerah bagi penciptaan generasi mendatang yang menguasai konsep-konsep pemanfaatan sumberdaya lingkungan bagi pelestarian kapasitas memproduksi bahan pangan dan bahan lain yang diusahakan dengan berbasis pada pemanfaatan tumbuhan.

Buku ini memuat kajian tentang ekologi penyakit, epidemiologi dan pemanfaatannya, musuh alami patogen dan pemanfaatnnya, strategi pengendalian penyakit, dan program pengelolaan penyakit tanaman secara terpadu.

Buku ini merupakan bagian dari materi kuliah Pengelolan Hama dan Penyakit Tanaman Terpadu, di mana sebelum mengikuti mata kuliah ini mahasiswa harus sudah mempelajari Dasar-dasar Ilmu Hama, Ilmu Penyakit atau Penyakit atau Dasar-dasar Perlindungan Tanaman. 
Mata kuliah Pengelolaan Penyakit ini dapat memberikan pemahaman dan bekal pengetahuan bagi calon Sarjana Pertanian dalam menyusun tugas akhir yang terkait dengan bidang Perlindungan Tanaman sekaligus sebagai bekal untuk menghadapi bidang kerja pertanian yang senantiasa menghadapi kendala akibat gangguan patogen penyebab penyakit sebagai respons dari dinamika agroekosistem dan berbagai tekanan akibat degradasi kualitas lingkungan hidup melalui pengaplikasian teknologi pengelolaan Penyakit secara terpadu.

\subsection{Standar Kompetensi}

Mahasiswa mampu merencanakan dan mengaplikasikan konsep pengelolaan hama dan penyakit secara terpadu dengan mengintegrasikan seluruh sumberdaya dan teknik pengendalian yang memungkinkan Kompetensi yang ingin diharapkan dapat dicapai oleh pebelajar Ilmu Penyakit Tumbuhan (Phytopathology) adalah seperti dinyatakan dalam Tabel 1.1 . 
Tabel 1.1. Kompetensi dasar kajian Pengelolaan Penyakit Tanaman Terpadu

\begin{tabular}{|c|c|c|c|}
\hline No & Kompetensi Dasar & Capaian Pembelajaran & $\begin{array}{c}\text { Pokok dan Sub Pokok } \\
\text { Bahasan }\end{array}$ \\
\hline 1 & $\begin{array}{l}\text { Mahasiswa } \\
\text { memahami lingkup } \\
\text { dan batasan } \\
\text { pengelolaan penyakit } \\
\text { tanaman serta peran } \\
\text { dan manfaat mata } \\
\text { kuliah Pengelolaan } \\
\text { Penyakit Tanaman }\end{array}$ & $\begin{array}{lr}\begin{array}{l}\text { Mahasiswa } \\
\text { menjelaskan } \\
\text { dan lingkup }\end{array} \text { batasan } \\
\text { Pengelolaan } \\
\text { Tanaman (PPT), definisi } \\
\text { PPT, serta deskripsi dan } \\
\text { peran mata kuliah PPT }\end{array}$ & $\begin{array}{l}\text { Pendahuluan } \\
\text { a. } \text { Batasan dan } \\
\text { lingkup kajian } \\
\text { Pengelolaan } \\
\text { Penyakit Tanaman } \\
\text { b. Definisi } \\
\text { pengelolaan HPT } \\
\text { c. Deskripsi dan } \\
\text { peran mata kuliah } \\
\text { d. } \text { Sumber rujukan }\end{array}$ \\
\hline 2 & $\begin{array}{l}\text { Mahasiswa mampu } \\
\text { memahami konsep } \\
\text { ekologi di dalam } \\
\text { pengelolaan } \\
\text { penyakit tanaman } \\
\text { secara terpadu }\end{array}$ & $\begin{array}{l}\text { Mahasiswa dapat } \\
\text { menjelaskan aspek } \\
\text { ekologi pengelolaan } \\
\text { penyakit yang meliputi: } \\
\text { tinjauan ekosistem, } \\
\text { pengendalian dan } \\
\text { pengelolaan, ambang } \\
\text { ekonomi, dan integrasi } \\
\text { komponen pengelolaan } \\
\text { serta memberikan } \\
\text { contoh dalam PHPT } \\
\text { penyakit penting } \\
\text { tertentu }\end{array}$ & $\begin{array}{l}\text { Ekologi pengelolaan } \\
\text { organisme penyebab } \\
\text { penyakit: } \\
\text { a. Organisme } \\
\text { penyebab penyakit } \\
\text { (patogen) sebagai } \\
\text { komponen } \\
\text { ekosistem } \\
\text { b. Pengendalian dan } \\
\text { pengolaan penyakit } \\
\text { c. Ambang ekonomi } \\
\text { pengendalian } \\
\text { d. Integrasi komponen } \\
\text { pengelolaan }\end{array}$ \\
\hline 3 & $\begin{array}{lr}\text { Mahasiswa } & \text { mampu } \\
\text { memahami } & \\
\text { epidemiologi } & \text { dan } \\
\text { peramalan } & \text { penyakit } \\
\text { tanaman } & \text { serta } \\
\text { mampu menentukan } \\
\text { keputusan } & \text { dalam } \\
\text { tindakan } & \\
\text { pengendalian } & \\
\text { penyakit } & \end{array}$ & $\begin{array}{l}\text { Mahasiwa dapat } \\
\text { menjelasakan epidemi } \\
\text { dan peramalan penyakit } \\
\text { terkait: epidemiologi dan } \\
\text { pemanfaatannya bagi } \\
\text { pengelolaan penyakit, } \\
\text { modelling epidemi } \\
\text { penyakit tumbuhan, } \\
\text { peramalan penyakit, } \\
\text { serta keputusan } \\
\text { tindakan pengendalian } \\
\text { penyakit dengan } \\
\text { memberikan contoh } \\
\text { penyakit penting } \\
\text { tertentu }\end{array}$ & $\begin{array}{l}\text { Epidemi dan } \\
\text { peramalan penyakit } \\
\text { a. Epidemiologi: } \\
\text { struktur dan pola } \\
\text { b. Modelling epidemi } \\
\text { penyakit tumbuhan } \\
\text { c. Peramalan dan } \\
\text { Pemanfaatan } \\
\text { epidemiologi bagi } \\
\text { pengelolaan } \\
\text { penyakit }\end{array}$ \\
\hline
\end{tabular}


Tabel 1.1. Kompetensi dasar kajian Pengelolaan Penyakit Tanaman Terpadu (lanjutan)

\begin{tabular}{|c|c|c|c|}
\hline 4 & $\begin{array}{l}\text { Mahasiswa } \\
\text { mengetahui jenis- } \\
\text { jenis musuh alami } \\
\text { patogen penyebab } \\
\text { penyakit dan } \\
\text { menguasai teknik } \\
\text { dasar pemanfaatan, } \\
\text { formulasi, dan } \\
\text { teknik aplikasinya }\end{array}$ & $\begin{array}{l}\text { Mahasiswa dapat } \\
\text { menjelaskan (yang } \\
\text { disertai dengan contoh) } \\
\text { jenis-jenis agensia } \\
\text { hayati, pemangfaatan, } \\
\text { dan teknik aplikasinya } \\
\text { bagi pengendalian } \\
\text { penyakit penting } \\
\text { tertentu }\end{array}$ & $\begin{array}{l}\text { Musuh alami patogen } \\
\text { dan pemanfaatan agen } \\
\text { biokontrol: } \\
\text { a. Jenis-jenis agen } \\
\text { sia hayati } \\
\text { b. Pemanfaatan dan } \\
\text { formulasi } \\
\text { c. Teknik aplikasi }\end{array}$ \\
\hline 5 & $\begin{array}{l}\text { Mahasiswa mampu } \\
\text { memahami sistem } \\
\text { dan menguasai } \\
\text { teknik pengamatan } \\
\text { penyakit }\end{array}$ & 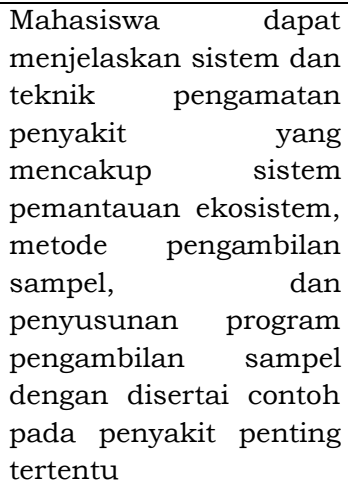 & $\begin{array}{l}\text { Sistem dan teknik } \\
\text { pengamatan penyakit } \\
\text { a. Sistem pemantauan } \\
\text { ekosistem dan } \\
\text { pengamatan penyakit } \\
\text { p. Metode } \\
\text { pengambilan } \\
\text { sampel } \\
\text { c. Determinasi } \\
\text { penyakit }\end{array}$ \\
\hline 6 & $\begin{array}{lr}\text { Mahasiswa } \\
\text { memahami } & \text { prinsip- } \\
\text { prinsip } & \text { aplikasi } \\
\text { metode pengendalian } \\
\text { penyakit tanaman } \\
\text { dalam } \\
\text { pengelolaan penyakit } \\
\text { secara terpadu dan } \\
\text { penyusunan program } \\
\text { pegelolaan penyakit } \\
\text { terpadu }\end{array}$ & 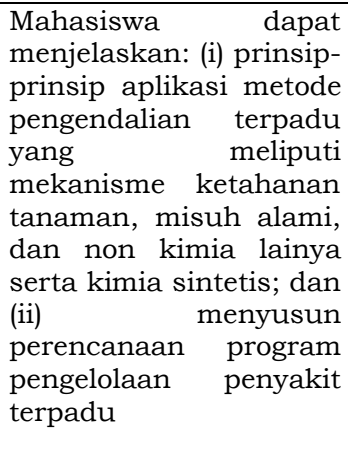 & $\begin{array}{l}\text { Prinsip-prinsip aplikasi } \\
\text { dan peyusunan } \\
\text { program pengelolaan } \\
\text { penyakit terpadu: } \\
\text { a. Prinsip-prinsip } \\
\text { aplikasi pengelolaan } \\
\text { peyakit (non kimia } \\
\text { dan kimia sintetis } \\
\text { toksik) } \\
\text { b. Penyusunan } \\
\text { program } \\
\text { pengendalian } \\
\text { penyakit terpadu }\end{array}$ \\
\hline
\end{tabular}


Tabel 1.1. Kompetensi dasar kajian Pengelolaan Penyakit Tanaman Terpadu (lanjutan)

\begin{tabular}{|c|lr|l|l|}
\hline No & \multicolumn{2}{|c|}{ Kompetensi Dasar } & $\begin{array}{l}\text { Pokok dan Sub Pokok } \\
\text { Bahasan }\end{array}$ & $\begin{array}{l}\text { Metode } \\
\text { Pembelajaran }\end{array}$ \\
\hline 7 & $\begin{array}{l}\text { Mahasiswa } \\
\text { menganalisis } \\
\text { melakukan } \\
\text { pelaksanaan } \\
\text { pengelolaan } \\
\text { terpadu } \\
\text { pertanaman } \\
\text { pascapanen }\end{array}$ & penyaluasi \\
dangga & dit & $\begin{array}{l}\text { Mahasiswa dapat } \\
\text { menjelaskan teknik } \\
\text { aplikasi pengelolaan } \\
\text { penyakit terpadu } \\
\text { tanaman pangan dan } \\
\text { sayuran/hortikultur, } \\
\text { tanaman perkebunan } \\
\text { dan agroforestri, serta } \\
\text { penanganan } \\
\text { pascapanen hingga di } \\
\text { gudang penyimpanan }\end{array}$ & $\begin{array}{l}\text { Aplikasi pengelolaan } \\
\text { penyakit terpadu } \\
\text { tanaman pangan } \\
\text { dan hortikultur, } \\
\text { tanaman } \\
\text { perkebunan dan } \\
\text { agroforestri, serta } \\
\text { produk padcapanen } \\
\text { dan penyimpanan }\end{array}$ \\
\hline
\end{tabular}

\subsection{Lingkup dan Batasan}

Pengelolaan Penyakit Tanaman Terpadu adalah semua kegiatan yang dimulai dari perencanaan sampai pada pelaksanaan yang bertujuan melindungi tanaman agar mampu menghasilkan produksi sesuai harapan dan dialkukan secara terpadu.

Dalam pengelolaan penyakit tanaman ada upaya upaya untuk mencegah dan mengendalikan berbagai pathogen pengganggu tanaman yang dimensinya umumnya mikroskpis. Jamur, bakteri, dan virus masing-masing berdiameter paling kecil dapat mencapai sekitar 2,0, 0.4, $\leq 0,05 \mu \mathrm{m}$; terlalu kecul dibandingkan ukuran sel tanaman rata-rata lebih besar dari $15 \mu \mathrm{m}$.

Tiga hal penting dalam konteks kajian ilmu penyakit dan pengelolaannya yaitu: 
(i) Patogen (penyebab penyakit), adalah organisme dalam dunia Jamur, Bakteri, Virus, dan organisme yang berperilaku parasitisme terhadap tanaman;

(ii) Tanaman, yaitu organisme dalam dunia plantae yang dibudidayakan untuk dimanfaatkan pada fase pertumbuhan dan/atau hingga pada akhir fase generatifnya. Di lain pihak organisme serupa namun berbeda peran utamanya sering menjadi faktor penentu keberhasilan pembuddiayaan tanaman untuk tujuan produksi. Organsime dikenal disebut sebagai tumbuhan; yaitu organisme dalam dunia plantae yang tidak dibudidayakan tetapi bisa bermanfaat bagi manusia dan/atau baik langsung maupun tidak langsung bagi keperluan pengelolaan hama dan penyakit tumbuhan;

(iii) Lingkungan, adalah segala sesuatu baik yang hidup (biotik) maupun tidak hidup abiotik baiklangsung maupun tidak langsung berpengaruh pada kejadian penyakit dan menjadi penentu keberhasilan pengendalian. Sementara organisme plantae yang disebut tumbuhan sering kali menjadi bagian dari faktor lingkungan yang sangat menentukan produktivitas tanaman yang dibudidayakan bahkan bertanggung-jawab terhadap eksistensi patogen. 
Interaksi ketiga faktor utama itu kemudian memunculkan kejadian penyakit. Jika ditambah dengan unsur waktu, maka penjelasan tentang kejadian penyakit menjadi lebih komprehensif karena kuatlemahnya patogen akan akan terwujud secara epidemiologi sejalan dengan perubahan waktu.

Target dari implementasi ilmu Pengelolaan Peyakit Tanaman Terpadu adalah terselamatkannya produksi tanaman, yaitu hasil kinerja tanaman yang dibudidayakan baik dalam bentuk:

(a) produk dari pertumbuhan vegetatif: sayur, getah/resin, kayu (teras dan/atau gubal)

(b) produk dari pertumbuhan adan/atau hasil akhir fase generatifnya: buah-buahan, biji;

(c) serta hasil ikutan yang bermanfaat baik langsung maupun tidak langsung bagi keperluan manusia: air, gas $\mathrm{O}_{2}$, serapan $\mathrm{CO}_{2}$. 


\section{Pertanyaan Bab 1:}

1. Jelaskan perbedaan pengelolan dan pengendalian peyakit?

2. BIdang ilmu dan keahlian apa saja yang dibutuhkan dalam kajian dan implementasi Pengelolaan Penyakit Tanaman Terpau. 


\section{BAB 2 \\ EKOLOGI PENGELOLAAN PENYAKIT}

\subsection{Ekologi Penyakat}

Dari definisi yang disampaikan berbagai ahli sejak awal (Ernst Haeckel, 1866), Charles Elton (1927), E. P. Odum (1963), C. J. Krebs (1972), dan G. Tyler Miller (1975) higga kini, dapat disimpulkan suatu pemahaman Ekologi, yaitu adalah ilmu pengetahuan komprehensif yang mempelajari hubungan interaksi antara satu organisme dengan organisme lain dan dengan lingkungannya yang mencerminakn distribusi dan kelimpahan organisme. Jadi ekologi mempelajari tentang struktur dan fungsi alam.

Dari definsi Ekologi secara umum dapat ditarik ke dalam ranah Ilmu Penyakit yang kita sebut sebagai Ekologi Penyakait. Hubungan timbale balik yang terjadi dalam ranah ini dalah hubungan antara organisme pathogen dengan ligkungannya baik biotic maupun abiotik. Pengetahuan tentag ekologi penyakit ini akan mendasari penentuan strategi dan metode pengendalian hama.

Faktor biotik dalam ekologi penyakit dapat diuraikan menjadi sebagai berkut:

(i) daya reproduksi pathogen, adalah kemampuan orgnise pathogen dalam mereproduksi dan melakukan perkembangbiakan. Virulensi dan 
kemampuan reproduksi akan mempengaruhi keseimbangan dalam eksistem penyakit. Kemampuan reproduksi yag tinggi dapat menimbukan kejadian penyakit yang parah dan massif sehingga dapat menghancurkan pertanaman pertania.

(ii) daya survivalitas dan penyebaran pathogen; factor ini sanga menjadi perhatian para ahli penyakit. Fusarium dapat bertahan sebagai saprofit ketika tidak ditemukan inang yang sesuai, namun ketika tanaman inang tersedia amur ini menjadi pathogen yang mematikan. Berbagai pathogen air borne dapat berpindah jauh sehingga jkemamuan penyebaranya menjadi tinggi. Sementara itu pathogen soil borne yang penyebarannya dibantu oleh aliran air sesungguhnya penyebaranya lebih terbatas, namun air irigasi dan badan air lain dapat memfasilitasi penyarannya meliputi area yang laus seperti pathogen air borne;

(iii) sumber nutrisi (kuantitas dan kualitas) yang dalam hal ini adalah kesesuaian dan nilai gizi yang terkandung dalam tubuh tanaman (daun, batangm akar, buah, bunga) dan bahan organik berupa biomassa atau berangkasan tanaman.

(iv) Parasit, adalah organisme yang dapat menimbulkan peyakitdan/atau memparasitasi 
pathogen penyebab penyakit. Organisme ini sering disebut sebagai agen biokontrol. Kehadiran organis dengan status sebagai parasit ini akan menjaid factor penentu keberhasilan patofen untuk menumbuhkan populasi dan dalam penyebarannya;

(v) Kompetitor; yaitu jenis organisme lain yang tumbuh dalam habitat yang sama dengan niche yang bisa sama ataupun berbeda. Beberpa Trichoderma serin mengembangkan mekanisme kompetisi untuk menekan pathogen dan memulihkan gejala penyakit yang disebabkan oleh patogen tertentu [3].

(vi) Vektor; banyak jenis serangga menjadi vector pathogen. Serangga kutu wereng coklat selain sebagai hama juga sebagai vector yang dapat menularkan pathogen penyebab peyakit Rice grassy stunt virus dan Rice ragged stunt virus pada tanman padi [4-5].

Faktor abiotik yang mempengaruhi kehidupan suatu organisme ditentukan oleh:

(i) Suhu; pada kisaran suhu tertentu organismedapat tumbuh dan bekembang-biak secara optimal; di luar kisaran tersebut pathogen dapat terhambat kehidupannya;

(ii) Curah hujan, basanya sangat mempengaruhi kelembaban relative udara $(\mathrm{RH})$. Lapisan air 
yang tipis di permukaan daun akan menciptakan kelembaban di permukaan daun yan memfasilitasi kemudahan dalam melakukan infeksi oleh pathogen;

(iii) Sinar matahari, dalam hal ini intensitas dan lama penyinaran iasanya sangat mempengeruhi aktiitas patgen seperti sporulasi dan perkecamabahan;

(iv) Kelembaban realtif udara $(\mathrm{RH})$; kisaran $\mathrm{RH}$ tiap jens pathogen khas dan tidak sama denga kebutuha akan kelemaban reatif udara dengan pathogen lainnya;

(v) Angin, kecepatan angin sangat mempengaruhi penyebaran spora pathogen air borne. Angin dapat memindahkan spora dan membuat penyeakit tersebar meluas dalam waktu singkat karna difasilitasi oleh pergerakan angin.

Ekosistem. Interaksi dinamik antara komponenkomponen biotik dan abiotik membntuk suatu system yang rumit yg tersusun oleh semua organisme hidup pd suatu daerah dengan lingkungan fisiknya (tanah, air, iklim, habitat). Sistem yang terbentuk dari intraksi tersebut disebut sebagai ekosistem.

Di dalam ekosistem terdapat aliran energi yang ditunjukkan pada rantai makanan, dengan penjelasan:

(i) Tiap tingkat dari rantai makanan disebut tingkat trofi atau taraf trofi. Karena organisme pertama 
yang mampu menghasilkan zat makanan adalah tumbuhan maka tingkat trofi pertama selalu diduduki tumbuhan hijau atau produsen.

(ii) Tingkat selanjutnya adalah tingkat trofi kedua, terdiri atas hewan pemakan tumbuhan yang biasa disebut konsumen primer. Pada level ini termasuk juga pathogen penyebab penyakit dan hewan hama. Sebagai konsumen primer, Jamur dan hewan yang secara taksonomi merupakan organisme yang berbeda sangat jauh satu sama lain namun bisa berada pada tempat hidup yang sama yaitu pada satu jenis inang di satu individu tanaman yang sama. Contoh ini adalah kutu daun (Phenacoccus manihoti dan P. marginatus) dan tungau merah (Tetranychus urticae) bersama sama dengan pathogen peyebab bercak daun menyerang satu individu tanaman singong [6];

(iii) Hewan pemakan konsumen primer merupakan tingkat trofi ketiga, terdiri atas hewan-hewan karnivora.

Energi dalam ekosistem akan berdinamika menuju stabiltas ekosistem yang ditunjukkan oleh:

(i) Jalinan atau gabungan berbagai rantai makanan yang saling berhubungan atau bertautan satu sama lain dalam ekosistem memebntuk jaringjaring makanan; 
(ii) Dalam ekosistem rantai makanan-rantai makanan itu saling bertalian membentuk jaringjaring makanan (food web);

(iii) Semakin tinggi diversitas dalam suatu ekosistem, maka semakin kompleks jaring-jaring makanan maka stabilitas ekosistem tersebut semakin tinggi

Satu rantai makan dengan rantai makanan lainnya di dalam suatu ekosistem akan membentuk jarring-jaring makanan yang lebh rumit dan sangat menentukan dinamika dan stabiltas ekosistem itu sendiri.

\subsection{Pengelolaan Agroekosistem}

Agroekosistem adalah ekosistem yang terbentuk karena adanya campur tangan manusia dalam proses budidaya tanaman dengan tujuan untuk memperoleh hasil pertanian yang tinggi.

Pada agroekosistem didominasi oleh jenis-jenis tanaman yang dipilih oleh petani baik dengan pola tanam monokultur atau tumpang sari. Umur tanaman pada agroekosistem juga umumnya relatif sama struktur fenologinya juga sama.

Di dala, agroekosistem dijumpai keragaman (diversitas), yaitu:

(i) Keadaan di mana jenis dan umur tanaman pada suatu agroekosistem relatif sama, menyebabkan jaring-jaring makanan dan diversitas pada 
agroekosistem lebih rendah apabila dibandingkan dengan ekosistem alami.;

(ii) Beberapa ahli ekologi dan entomologi mengatakan, meskipun jaring-jaring makanan pada agroekosistem lebih sederhana, namun masih cukup kompleks dan dinamis);

(iii) Berbagai organisme sebagai komponen pembentuk agroekosistem mempunyai peran sebagai produsen (tanaman), herbivora, predator, parasit, dan dekomposer.

Di dalam agroekosisem akan tampak peran arthropoda pada agroekosistem. Berbagai jenis Arthropoda yang ada pada agroekosistem mempunyai peran yang beragam antara lain sebagai herbivora, predator, parasitoid, pemakan plankton, dan dekomposer. Arthropoda tersebut saling berinteraksi dan membentuk jaring-jaring makanan. Pada agroekosistem dengan diversitas yang tinggi akan terbentuk jaring-jaring makanan yang lebih kompleks, sehingga mendukung terciptanya agroekosistem yang stabil.

Di dalam agroekosistem terapat beberapa input yang berasal dari luar (bukan indigen), yaitu terdiri dari: benih atau bibit yang akan dbudidaya kan dan menjadi sentral dalam pengelolaan agroekosistem serta menjad tujuan dalam pengelolaannya; (ii) sumber energi atau sumber tenaga ayang akan digunakan untuk 
mengerekkan kegiatanb budidaya dan pengelolaan agroekosistem seperti: bahan bakar (BBM), tenaga ternak, tenaga manusia; dan (iii) bahan kimia baik anorganik atau buatan maupun bahan organic, terdiri atas: pupuk dan pestisida; (iv) air yang dialirkan melalui irigasi dan berasal dari sumber air di hulu mengalir melalui sungai; (v) organisme eksotik, yaitu organisme yang seara sengaja dimasukkan maupun yang terbawa oleh angin dan factor biotic dan abiotik lannya. Oranisme yang menguntungkan bersumber dar luar uslaya pupul hayati (Trichoderma, mikoriza, bakteri bintil akar, dan lainnya); sedangkan yan bersifat merugikan atau data menimbulkan gangguan adalah berbagai OPT (jamur dan bakteri pathogen srta virus) yang kadang masuk ke dalam agrekosistem secara massif dan sukar terkendalikan.

Beberapa karakeristik agroekosistem yang perlu mendapat perjatian dalah meliputi:

(i) Tidak memiliki kontinuitas atau selalu berubahubah misalnya mikroklimat di pertanaman yang sangat dipengaruhi oleh berbagai factor baik bioti maupun abiotik;

(ii) Strukturnya didominasi oleh jenis tanaman tertentu yang dipilih atau oleh organisme jenis lain yang bersesuaian dengan jenis tanaman yang dibudidayakan; 
(iii) Keragaman genetik yang relatif rendah, apalgi pada system pertanaman mooultur. Sawah, perkebunan tertentu, dan hutan tanaman biasanya merupakan ekosistem yang keragaman geentiknya jauh lebih rendah dbandingkan hutan alam atau kawasn konservasi;

(iv) Bentuk dan umur tanaman umumnya sama; berbeda dengan hutan alam, eksositemnya akan terdiri atas bentuk dan umur vegetasi yang bergam;

(v) Banyak masukan unsur-unsur hara tanaman berasal dari pross pemupukan. Kondisi ini biasanya ditujukan untuk mencapai produktivitas lahan yang tinggi. Namun pada ekosistem yang demikian biasanya produksi atau hasil panen tinggi tapi seringkali rentan digangguan OPT;

(vi) Mudah terjadi endemic penyakit tertentu di mana tanaman yang dibudidayakan rentan terhadap gangguan penyakit tnaaman.

Pengelolaan agroekosistem yang baik akan menjaga berlangsungnya rantai makanan, sehingga keseimbangan ekosistem dapat tercapai.

Hal itu berarti peningkatan populasi hama dapat dihindari dg cara pengelolaan agroekosistem yang benar dan bijaksana. 
Pertumbuhan populasi. Jika populasi tumbuh terus dan jumlah individu meningkat maka akan berakibat: (i) ketersediaan sumber daya akan berkurang, dan (ii) terjadi kompetisi antar individu meningkat.

Di dalam pertumbuhannya, terjadi dinamika dalam populasi yang disebabkan oleh beberapa hal, yaitu:

(i) Faktor intrinsik (berkerja dalam individu) dan ekstrinsik (berasal dari luar).

(ii) Faktor biotik (disebabkan oleh organisme) dan abiotik (berasal dari lingkungan).

(iii) Faktor yang tergantung densitas (density dependent factor) dan faktor yang tidak tergantung densitas (density independent factor).

Faktor intrinsik dalam populasi yaitu meliputi stress dan teritorialitas, polimorfisme genetic, dan penyebaran. Sementara itu faktor ekstrinsik yang mempengaruhi dinamika populais adalah melipui:

(i) penyakit; yaitu suatu keadaan gangguan fisiologi yang disebabkan oleh oleh adanya parasitasi atau ganguan oleh mikrooransme lain, misalnya serangan virus dan bakteri tertentu;

(ii) Kompetisi, adanya persaingan dalam memanfaatkan sumberdaya berupa makanan dan tempat hidup. Kompetisi bisa terjadi antara pathogen dan musuh ahli; 
(iii) Faktoer abiotik, yaitu seluruh komponen lingkungan yang bukan organisme hidup akan sangat mempengaruhi dinamika serangan pathogen. Suhu, kelembaban udara, intensitas dan lama penyinaran sinar matahari, curah hujan, dan pergerakan angin merupakan actor abiotik yag memepengaruhi dinamika pathogen dalam melakukan aktivitas serangannya.

Pengelolaan penyakit secara terpadu (PHT) sesungguhnya adalah pengelolaan agroekosistem dalam perspektif Ilmu Penyakit Tanaman. PHT merupakan sistem pengendalian hama yang mengutamakan pengelolaan agroekosistem. PHT mendorong berfungsinya mekanisme pengendalian alami spt pemanfaatan musuh alami, penggunaan varietas tahan, budidaya tanaman sehat, pengaturan pola tanam, dan metode lainnya yang meminimalkan efek negative berupa ganguan terhadap stabilitas agroekosistem itu sendiri. 


\section{Pertanyaan Bab 2:}

1. Secara ekologi, organisme pathogen adalah komponen eksosiem. Mengapa pathogen menjadi ancaman bagi kelestarian kemampuan produksi optmal tanaman yang dibudidayakan? Jelaskan.

2. Apa yang harus diubah atau ditekan dalam rantai makan di suatu agroekosistem? Apa juga yang harus didorong untuk tumbuh lebih optimal beberpa komponen agroekosism agar produksi tanaman terjaga?

3. Bentu interaksi apa saja yang perlu diperhatikan dalam agroekosistem agar dapat mendukung perlindungan tanaman? 


\section{BAB 3 \\ EPIDEMIOLOGI DAN PERAMALAN}

Banyak kejadian penyakit tanaman tertentu berbeda intensitas dan luas serangannya antara di suatu pulau dengan pulau lainnya, di suatu provinsi dengan provinsi lainnya. Bahkan di kawasan yang berdekatan, misalnya di dalam satu kabupaten bisa berbeda intensitasnya. Sementara itu dari suatu waktu ke waktu tertentu yang berarti terdapat perbedaan rata-rata kondisi lingkungan, sering menunjukkan intensitas yang berbeda. Serangan Phytopthora infestans pada musim hujan yang didominasi oleh intensitas rendah hingga sedang namun dengan frekuensi yang tinggi ternyata menimbulkan kerusakan berat pada tanaman kentang di sentra pertanaman kentang di JurangkualiSumberbrantas, Batu. Di lain keadaan, pada musimkemaray atau intensitas curah dan frekuensi hujan yang rednah menunjukkan gejala serangan yang ringan sampai sedang. Fakta ini mengindikasikan betapa besarnya pegaruh lingkungan terdapat kenunculan dan perkembangan penyakit.

Kita juga serng melihat fakta munculya gejala serangan penyakit seperti tiba-tiba datangnya atau hanya membutuhkan waktu yang pendek di sebagian wilayah Batu (Jawa Timur), semantara itu di wilayah yang berjarak terdekat sekitar 5-10 km di senra kentang 
di Pujon serangannya lambat hingga mencapai puncak serangan dua hingga tiga bulan berikutnya di kurun waktu yang sama. Hal ini menunjukkan bahwa ada faktor kepadatan propagul pathogen yang mempengaruhi kondisi awal serangan. Selain itu ada factor lingkngan spesifik pada kurun waktu yang sama yang berbeda di antara kedua sentar pertanaman kentang tersebut.

\subsection{Epidemiologi}

Hubungan antara berbagai factor lingkungan, waktu, dan kepadatan awal propagul pathogen tersebut merupakan fungsi intensitas serangan penyakit. Kajian peroalan yang diilustrasikan tersebut disebut sebagai epedemiologi [7].

Kajian epidemiologi penyakit tanaman sesungguhnya merupakan kajian yang mempelajari struktur dan pola epedemi, modelling epidemi penyakit tanaman, serta pemanfaatannya bagi penyusunan dan pelaksanaan program pengelolaan penyakit tanaman.

Epidemiologi adalah ekologi penyakit dan aplikasi praktisnya dalam pengelolaan penyakit. Hal ini berkaitan dengan aspek kuantitatif penyakit pada tingkat individu populasi, dan ekosistem. Selanjutnya dikemukakan bahwa memahami bagaimana penyakit pada tiap tingkatan tersebut berubah menurut waktu dan ruang merupakan hal yang penting (kritis) dalam upaya untuk mengendalikan penyebarannya. 
Van der Plank (1963)[2] menggolongkan epidemi penyakit tanaman dalam dua kelompok yaitu:

(i) Penyakit Simple interest yaitu penyakit yang sumber inokulumnya tertentu dan peningkatan penyakit berdasarkan waktu menurut deret hitung,

(ii) Penyakit Compound interest yaitu penyakit yang memiliki sumber inokulum sekunder yang berkembang dari infeksi primer, dan peningkatan penyakit bersifat eksponensial.

Patogen dan inang sebagai komponen suatu ekosistem akan berinteraksi sepanjang waktu dengan evolusi dan koevolusi sebagai hasil responsnya terhadap perubahan kondisi lingkungan. Dalam kajian fitopatologi, unsur-unsur "segitiga penyakit" yaitu inang, patogen, dan lingkungan saling berinteraksi yang dalam perkembangannya dipengaruhi oleh unsur keempat yaitu waktu dan dikenal sebagai segi empat epidemi penyakit (Gambar 3.1). 


\section{SEGITIGA EMPAT \\ EPIDEMI PENYAKIT}

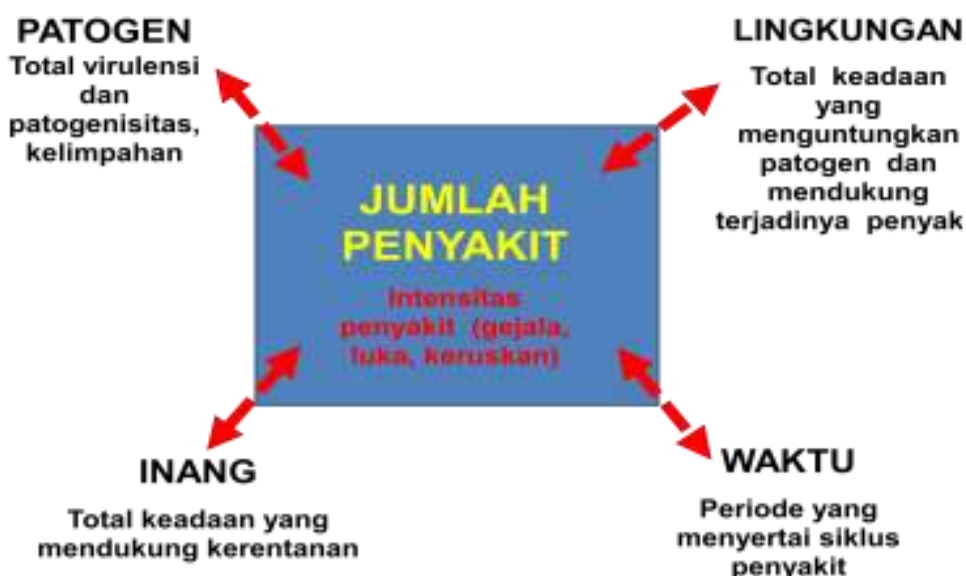

Gambar 3.1. Segi empat epidemi penyakit

Dari segi patogen, kinerja parasit yang mencerminkan adanya suatu evolusi, dengan komponennya: kemampuan selektif populasi parasit yang baru (wujud ekspresi gen), efisiensi infeksi, periode laten, produksi inokulum, virulensi, dan ketahanan nonparasitik. Untuk segi tanaman, biasanya dilihat pada penampilannya dalam hal ketahanan terhadap serangan patogen. Seleksi, pemuliaan, bahkan sampai rekayasa genetika biasanya dilakukan untuk tujuan mencari varietas tahan atau toleran.

Lingkungan baik biotik maupun abiotik akan sangat berpengaruh terhadap patogen dan inang. Tahap pradisposisi, inokulasi, dan keberhasilan infeksi, sangat 
dipengaruhi oleh berbagai faktor lingkungan seperti: suhu, kelembaban, cahaya, dan nutrisi. Kelembaban nisbi udara bersama-sama dengan kebasahan daun berpengaruh terhadap produksi dan pelepasan inokulum [8].

Suhu udara tidak hanya berpengaruh pada patogen tular udara, tetapi juga terhadap patogen tular tanah; faktor lingkungan ini terutama secara langsung mempengaruhi ketahanan inang terhadap serangan patogen. Suhu dan kelembaban juga mempengaruhi ketahanan inokulum patogen yang terakumulasi di tanah.

Manfaat kajian epidemiologi adalah dapat dimanfaatkannya model matematika yang diperoleh dari pengukuran pertumbuhan indeks penyakit sebagai akibat pengaruh lingkungan terhadap kehidupan patogen yang dimulai dari keberhasilan proses disposisi spora atau bentuk lain yang menyebabkan penyakit.

Hasil penelitian epidemiologi penyakit hawar daun bibit Pinus merkusii diperoleh model matematika terbaik yang ditentukan berdasarkan data hasil pengamatan tiap dua minggu terhadap seluruh komponen epidemi yaitu [8]:

$$
\begin{aligned}
& Y=142-1,4 X_{1}-10,6 X_{2}+3,86 X_{3}+0,308 X_{4}+ \\
& 0,0430 \mathrm{X}_{5}-1,05 \mathrm{X}_{6}-1,59 \mathrm{X}_{7} \\
& (\mathrm{R} 2=70,2) \text {; dengan penjelasan bahwa: }
\end{aligned}
$$




$$
\begin{aligned}
\mathrm{Y}= & \Delta \text { Indeks Penyakit } \\
\mathrm{X}_{1}= & \text { jumlah konidiospora yang tertangkap dari } \\
& \text { udara per } \mathrm{cm}^{2} \text { gelas perangkap } \\
\mathrm{X}_{2}= & \text { kecepatan angin rata-rata harian pada } \\
& \text { ketinggian } 0,5 \mathrm{~m}(\mathrm{~km} / \mathrm{jam}) \\
\mathrm{X}_{3}= & \text { kecepatan angin rata-rata harian pada } \\
& \text { ketinggian } 2,0 \mathrm{~m}(\mathrm{~km} / \mathrm{jam}) \\
\mathrm{X}_{4}= & \text { curah hujan rata-rata harian }(\mathrm{mm}) \\
\mathrm{X}_{5}= & \text { lama penyinaran matahari rata-rata harian (\%) } \\
\mathrm{X}_{6}= & \text { kelembaban nisbi udara rata-rata harian }(\%) \\
\mathrm{X}_{7}= & \text { suhu udara rata-rata harian }\left({ }^{\circ} \mathrm{C}\right) .
\end{aligned}
$$

Dari ketujuh komponen epidemi tersebut ternyata curah hujan dan lama penyinaran sinar matahari yang berpengaruh nyata meningkatkan pertambahan indeks penyakit secara berbanding lurus. Dari kasus ini ketika pada bulan atau periode tertentu di mana rata-rata pertambahan curah hujan dan lama penyinaran tiap dua mingguan di atas rata-rata, maka sudah harus diwaspadai ancaman kerusakan penyakit lebih parah. Upaya pencagahan pertumbuhan indeks penyakit itu perlu disempurnakan dengan melakukan monitoring status awal gejala penyakit sehingga dapat ditentukan tindakan yang dilakukan terhadap pertanaman apakah perlu dilakukan pengendalian secara kimia atau cukup dengan menseleksi dan memisahkan tanaman sakit atau memusnahkan tanaman atau bagiannya yang berpotensi sebagai sumber inokulum. 
Interaksi antara pathogen, tanaman, lingkungan, dan waktu akan membentuk suatu pola yang mencerminkan model epidemic suatu penyakit (Gambar 3.2).

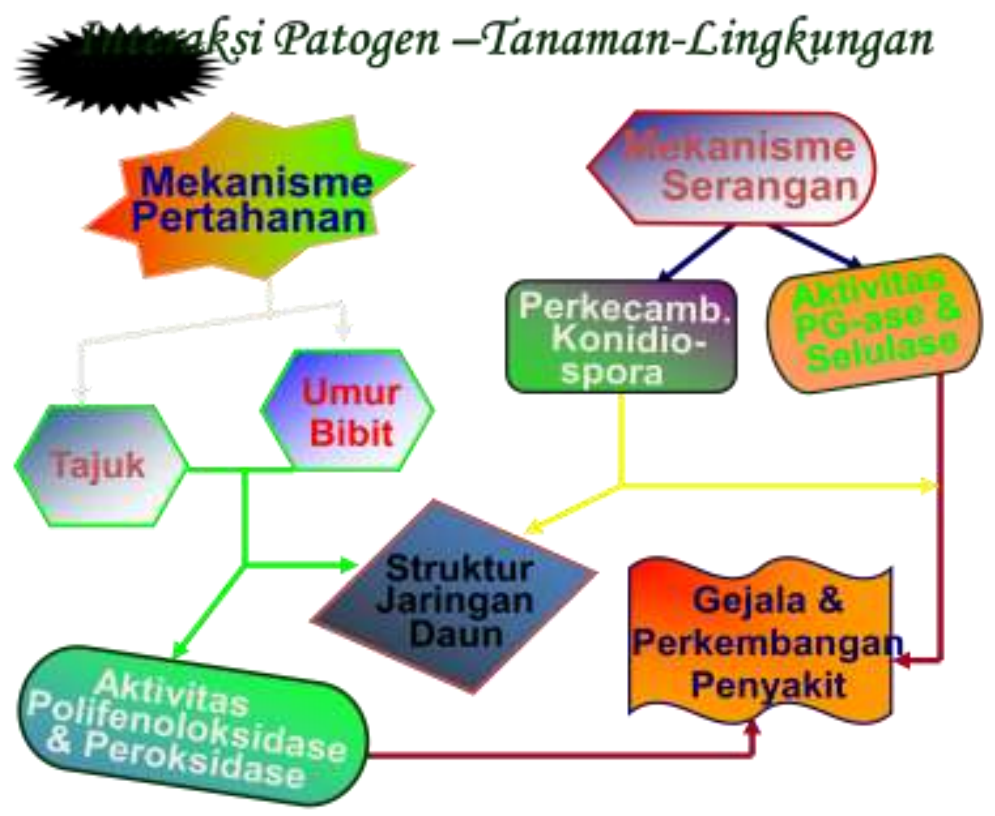

Gambar 3.2. Interkasi pathogen, tanaman, dan lingkungan sebagai gambaran model epidemi

Hipotesis epidemiologi suatu penyakit tanaman:

(i) Terdapat hubungan yang erat antata komponen epidemi dengan berat serangan;

(ii) Perbedaan lokasi pesemaian akan berpengaruh terhadap intensitas serangan;

(iii) Sumber inokulum dapat beraal dari inang lain dan dapat juga berasal dari tanah lapisan atas, 
di mana sumber inokulum terdeposit di top soil dalam kurun waktu tertentu.

Tanaman lain baik yang sejenis maupun berbeda jenis (inang alternatif) dapat enjudi sumber inoklum yang efektif bagi serangan penyakit. Biasa ini terjadi pada epidemic tipe yang compound interest. Makin banyak tumbuhan sebagai sumber inoklum, maka waktu yang diperlukan untuk mencapai intensitas serangan tertentu makin cepat. Kemungkinan lainnya adalah dalam kururn waktu yang sama, makin banyak tumbuhan sebagai sumber inokulum, maka intensitas serangan semakin tinggi seperti ditunjukkan pada Gambar 3.3.

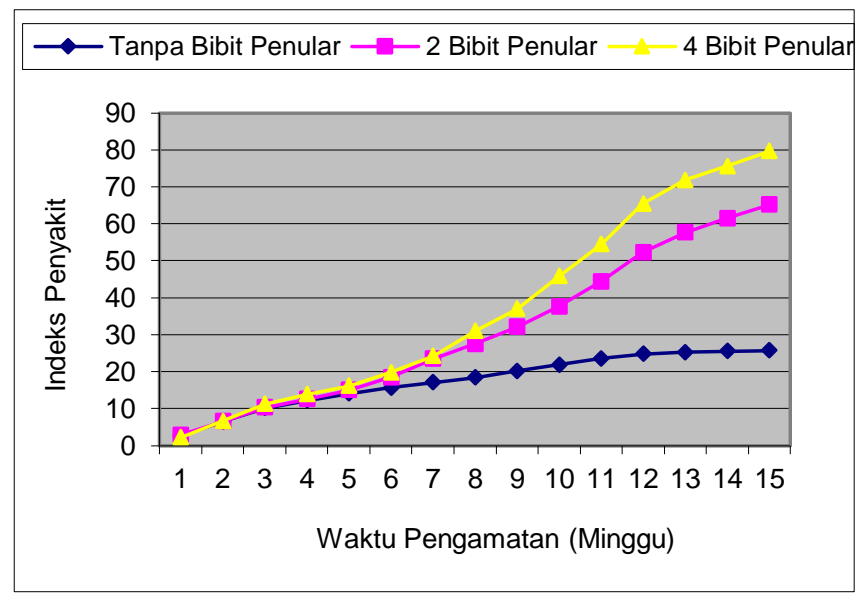

Gambar 3.3. Pengaruh jumlah bibit tanaman sakit sebagai penular dalam terhadap indeks penyakit kelompok bibit tanaman pinus selama 15 minggu [8]. 
Faktor lingkungan lain yang berpera penting dalam epidemic suatu penyakit di anataya adalah dinamika tingkat kesuburan tanah. Epidemi penyakit kanker batang pada tanaman karet (Hevea brasiliensis) di Sumatera Selatan yang disebabkan Lasiodiplodia theobromae dipengaruhi oleh kondisi fisik-kimia tanah; beratnya penyakit kandungan nitrogen tanah, debu, tanah liat, dan air serta kapasitas tukar kation (KTK) [9].

Faktor lingkungan biotik yang penting dalam penyebaran dan menciptakan sumber inokulum yang efektif adalah benih. Banyak jenis bakteri pathogen terbawa benih yang kemudian setelah berkecambah, maka infeksi awal sudah bisa dimulai. Hasil Identifikasi bakteri dengan PCR dengan menggunakan primer 63 F/1378R menunjukkan bahwa benih akasia membawa beberapa jneis bakteri patogenik bagi tanama akasia sendiri yaitu Micrococcus luteus, Burkholderia cepacia complex. Alcaligenes faecalis, Acinetobater sp., Pseudomonas stutzeri, Salmonella. bongori dan Ralstonia sp. [10].

Dengan pendekatan menggunakan model regresi dapat dicari hubungan antara indeks penyakit dengan variabel bebasnya meliputi pengaruh perbedaan ketinggian tempat dan umur bibit tanaman terhadap indeks penyakit [11]. 


\subsection{Teknik Penyusunan Model Epidemi}

Sebelum memulai menyusun model epidemiologi suatu penyakit, perlu dipahami suatu alur konsep yang menghubungkan antara berbagai komponennya (Gambar 3.4).

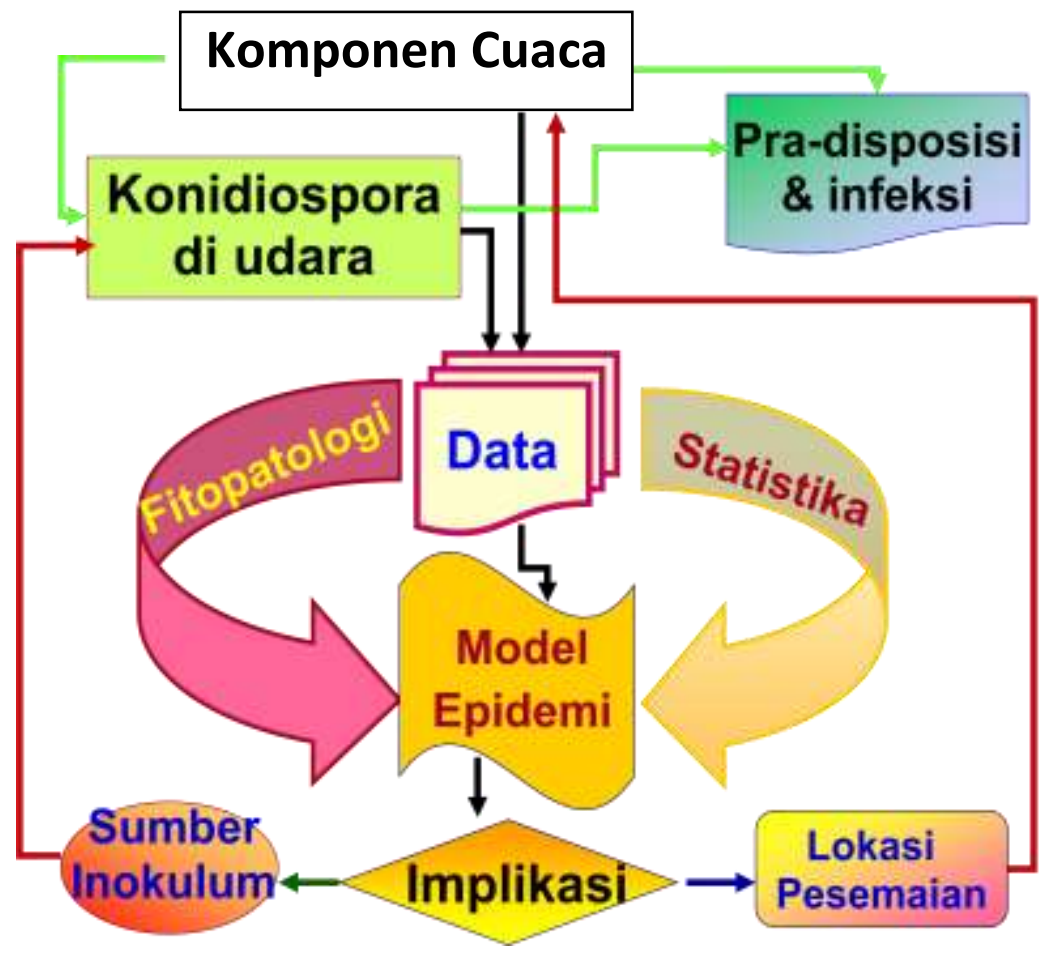

Gambar 3.4. Bagan alir proses penyusunan dan implementasi epidemiologi penyakit tanaman

Dalam pengamatan epidemiologi suatu penyakit untuk mendapatkan model epdeminya, dilakukan pengukuran berbagai komponen penting, yaitu: 
(i) Kepadatan propagul pathogen, biasanya dan yang paling mudah diamati adalah kandungan spora di udara. Teknik ini biasanya mengandalkan pada alat spore trap model Durham yang dimodifikasi (Gambar 3.5)
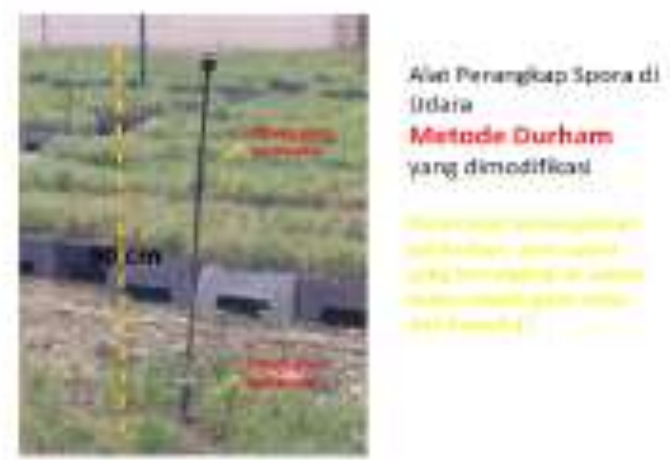

Idata

Metrode Durharm

vang dimndificad

Gambar 3.5. Spore trap model Durham yang dimodifikasi

(ii) Suhu udara $\left({ }^{\circ} \mathrm{C}\right)$ di lingkungan pertanaman yang diukur langsung oleh pengamat/peneliti. Dalam hal ini dapat dilakuka pendekatan dengan menggunakan data suhu dari stasion cuaca terdekat. Saat ini si pengamatan dapat menggunakan data suhu yang dibaca pada handphone yang memuat software dan dilengkapi dengan perangkatnya untuk mendapatkan data cuaca tiap harinya;

(iii) Kelembaban udara relative (\%), dapat diukur langsung dengan alat hygrometer dan 
terintegrasi dengan fungi pengukuran suhu udara;

(iv) Curah hujan (mm); untuk mendapatkan data curah pengamat akan memanfaatkan data dari stasion cuaca setempat yang memiliki peralatan standard untuk mengukur curah hujan secra tepat. Oleh karena itu, maka seluruh data komponen cuaca lainnya diambil juga dari stasion cuaca terdekat;

(v) Kecepatan angin (km/jam). Biasanya digunakan kecepatan angin pada ketinggian 50 $\mathrm{cm}$ dan ketinggian di atas $100 \mathrm{~cm}$. Masingmasing ketinggian ini memiliki peran yang berbeda dalam mempengaruhi penyebaran dan disposisi propagul pathogen. Pada ketinggian di atas $100 \mathrm{~cm}$ biasa efek turbulensi pergerakkan udara menjadi penting dalam penyebara dan keberhasilan disposisi pathogen;

(vi) Lama penyinaran matahari (jam per hari). Dalam kondisi harian yang didominasi keadaan mendung atau berawan, maka akan berpengaruh yang berbeda dibandingkan dengan kondisi cerah sepanjang siang hari.

Semua data yang tercatat dapat digunakan untuk menentukan model epidemic suatu penyakit. 
Perhitungannya dapat menggunakan soft ware Microsoft

- Excel dengan mengklik data analysis dan pilih regresi.

Data yang dimasukkan meliputi:

(i) Data yang menunjukkan nilai indeks penyakit yang dihitung berdasarka pengukuran intensitas gejala penyakit per sauna waktu tertentu, misalnya saja data indeks penyakit tiap minggu, tiap dua minggu, dan seterusnya tergantung kepentingan pengamat/peneliti;

(ii) Data yang menunjukkan konsentrasi atau banyaknya propagul pathogen yang tertangkap oleh suatu alat yang dipasang di pertanaman. Beberapa peneliti epidemiologi biasa menggunakan "spore trap" model Durham yang dimodifikasi sepert dicontohkan pada Gambar 3.5. Data propagul pathogen (misal spora, konidiospora) yang tertangkap di obyek glass (biasanya berlapiskan paraffin) diamati di bawah mikroskop dengan perbesar 100-400 kali. Data bisa diamati per hari, per minggu, atau periode waktu tertentu. Jika data yang digunakan adalah mingguan, jumlah spora harian dijumlahkan dalam satu minggu atau di rata-rata per hari;

(iii) Data komponen cuaca yang diperoleh dari stasion cuaca biasanya berupa data harian. 
Jika peneliti/pengemat ingin mengunakan data mingguan, maka data harian selama satu minggu dihitung rata-ratanya. Begitu juga jika ingin data dua mingguan, maka bisa dihitung rata-rata selama dua minggu.

D dalam tiap sheet maka masukkan kolom1 data indeks penyakit yang kemudian ini dianggap nilai $Y$ dalam model regresinya nanti; kolom 2 dan seterusnya adalah berisi data jumlah konidiaspora di udara (X1), keceptan angin $50 \mathrm{~cm}$ (X2), kecepatan angin $150 \mathrm{~cm}$ (X3), Curah hujan (X4), lama penyinaran sinar matahari (X5). kelembaban udara relative (X6), dan suhu udara (X7).

Sebagai contoh dari peruses penyusunan model epidemic berdasarkan data-data komponen yang dihitung, maja diperoleh model regresi berikut:

$$
\begin{aligned}
\mathrm{Y}= & 91,9-1,59 \mathrm{X}_{1}-13,1 \mathrm{X}_{2}+5,96 \mathrm{X}_{3}+ \\
& 0,437 \mathrm{X}_{4}+0,0802 \mathrm{X}_{5}-0,749 \mathrm{X}_{6}-1,02 \mathrm{X}_{7} \ldots(3.1) \\
R^{2}= & 83,2
\end{aligned}
$$

Dari data model regresi terebut diperoleh penjelasan dan intepretasi sebagai berikut. Dalam model ini dengan nilai $R^{2}=83,2$ menunjukkan keeratan yang tinggi antara indeks penyakit dengan berbagai komponen cuaca yang mempengaruhinya. Model ini sangat bisa dipercaya untuk menilai hubungan pengaruh berbagai kompnen cuaca tersebut terhadap perubahan indeks penyakit tanaman. Komponen curah hujan, lama penyinaran 
matahari, kelembaban udara relative, dam suhu berpengaruh nyata terdapat peningkaan indeks penyakit tanaman $(p<0,05)$. Pada kasus penyakit lain mungkin saja hasilnya berbeda; bahkan dapat terjadi bahwa kecepatan angin berpengaruh dengan tingkat siginifikansi yang tinggi terhadap pertumbuhan indeks penyakit tanaman. Tanda postif $(+)$ di tiap komponen epidemi tersebut menunjukkan penambahan indeks penyakit disebabkan oleh penambahan nilai satuan komponen cuaca tersebut. Dalam hal ini peningkatan curah hujan lama penyinaran sinar matahari, dan kelembaban udara serta penurunan suhu udara mempengaruhi peningkatan indeks penyakit. Dalam hal ini baik peningkatan maupun penurunan dri tiap komponen epidemic akan berada. Dalam hal ini baik peningkatan maupun penurunan dri tiap komponen epidemic akan berada pada kisaran intrinsik cuaca intrinsik cuaca di wilayah tersebut. Dalam hal ini kisaran suhu dan kelembaban di wilayah yang diukur epidemic penyekit tanaman tertentu tersebut misslanya antara $20-35{ }^{\circ} \mathrm{C}$ dan $65-98 \%$.

Untuk keperluan praktis, maka idelanya operator di lapangan sebagai pengguna informasi epidemi penyakit tertentu dapat mengunakan sedikit komponen epidemic yang akan diukurnya pada periode penanaman berikutnya. Dengan ketujuh komponen cuaca yang harus diukur tentunya akan sulit bagi petani 
melaksanakannya. Membuat modifikasi spore trap mungkin tidak sulit, tetapi mengamatinya hasil perangkap memerlukan mikroskop yang mahal dan ketrampilan seperti layaknya petugas/laboran terlatih. Untuk data cuaca yang lengkap bisa mendatangi stasion cuaca, tetapi ini juga memerlukan biaya transportasi dan waktu. Banyak stasion cuaca yang cukup jauh jarak tempuh lewat jalan umum dari lahan pertanian meski jarak nyata lahan-stasion cuaca sesungguh cukup dekat. Petani sesungguhnya bisa melengkapi areal pertanamannya dengan alat pengukur suhu dan kelembaban dalam satu alat.

Secara statistika kita dapat menyederhakan model agar komponen eidemi yang tampak dan dapat dijadikan acuan jumlahnya menjaid sedikit. Untuk itu perlu dilakukan langkap step regresi. Pada contoh model di atas, dapat disederhanakan menjadi:

$$
\begin{aligned}
& Y=104,135+0,075 X_{4}+0,40 X_{5}-0,70 X_{6}-1,48 X_{7} \ldots \\
& R^{2}=75,51
\end{aligned}
$$

Pada model hasil penyederhanaan tampak bahwa adanya keerat hubungan yang kuat antara indeks penyakit dengan semua komponen epidemiologi dengan nilai $\mathrm{R}^{2}=75,51$. Hasil penyederhaan ini masih belum sederhana, karena setidaknya ada empat komponen epidemic yang harus diukur atau datanya harus diperoleh. 


\subsection{Peramalan Penyakit}

Peramalan peyakit adalah suatu istilah dalam memprediksi status serangan penyakit tanaman tertentu dengan memanfaatkan model epidemiologi yang dibangun dari hasi penelitian atau hasil penghitungan hubungan antara pertubuhan intensitas serangan penyakit dengan komponen epidemic yang diukur dalam periode tertentu.

Status serangan ditunjukkan oleh indeks penyaki atau indeks luka, indeks serangan, atau intensitas gejala serangan penyakit. Variabel ini ditentukan dengan memasukkan data komponen epdemi dalam rumus atau model epidemic sehingga akan diperoleh nilainya. Biasanya indeks penyakit atau intensitas serangan penyakit ditunjukkan dalam persentasi dengan kisaran 0-100.

Untuk menentukan statsus serangan enyakt pada suatu waktu tertentu, diperlukan data lingkungan yang memadai terutama: suhu udara, kelembaban udara, curah hujan, lama penyinaran matahari, serta kepadatan spora di udara (untuk soil borne disease). Selai itu diperlukan juga informasi eksistensi inang alternatif sebagai sumber inokulum

Penentuan status serangan berdasarkan data komponen epidemic yang diukur pada saat tertentu tersebut bersifat sangat relatif (karena predksi) namun 
dapat digunakan sebagai pertimbangan dalam pengendalian penyakit.

Dengan asumsi bahwa semua komponen cuca megikuti pola seperti tertera pada model (rumus...(2)), maka petani atau pengguna data dapat melakukan pengukuran sendiri dengan menggunakan satu alat yaitu suhu dan kelembaban udara relative harian. Petani dapat mengukurnya ketika suhu terendah pada dinihari dan suhu tertinggi pada pukul 14.00 misalnya. Pada saat yang sama petani juga bisa melihat kelembaban udara relative. Dengan adanya penambahan suhu ratarata da kelembaban rata-rata udara yang lebih tinggi dari rata-rata harian, maka petani sudah dapat memperkirakan kemungkinan peningkatan intensitas serangan penyakit tanamannya. 


\section{Pertanyaan Bab 3:}

1. Jamur pathogen Pestalotia theae pada tanaman teh di Jawa tidak mampu menimbulkan kerusakan, namun pada bibit pinus (Pinus mersii) dapat menimbukan keruskaan parah. Jelaskan jawaban Anda menuru pendekatan epidemiologi?

2. Jelaskan mekanisme bekerja faktor-faktor epidemi yang digambarkan sebagai "segi empat" epidemi penyakit tanaman? Apa yang harus dilakukan untuk mencegah meningkatnya luas "segi empat" epidemi tersebut?

3. Apa manfaat kajian epidemiologi bagi pengendalian penyakit?

4. Apa yang Anda ketahui dengan peramalan penyakit? Bagaimana implementasinya bagi upaya pengelolaan peyakit? Jelaskan. 


\section{BAB 4 MUSUH ALAMI}

Musuh alami pathogen penyebab penyait adalah organisme yang aktivitasnya dapat menimbulkan kelainan fisiologis pathogen secara langsung dan/atau menimbulkan gangguan dan hambatan bagi aktivitas biologi pathogen. Organisme yang mempredasi pathogen juga termasuk sebagai musuh alami, misalnya nematode yang memakan jamur.

Musuh alami juga menjelaskan status kehidupannya yang berada di alam. Organisme yang selama ini dikenal memparasit, bersaing ntuk mendapatkan ruang dan makanan, menghambat, dan mempredasi pathogen sesungguhnya biasa terdapat di lingkungan pertanian atau di alam. Boleh jadi peristiwanya sudah belangsung sejak lama; dan yang saat ini mungkin saja berasal dari proses yang panjang di alam melalui mekanisme adaptasi dan koevolusi di antara organisem musuh alami dan pathogen serta dengan lingkungannya.

\subsection{Jenis-jenis Musuh Alami}

Berdasarkan taksonomi musuh alami dibedakan atas: jamur, bakteri, nematode, dan virus. Dari kempat macam musum alami tersebut, jenis jamur dan bakteri paling banyak dikenal dan dimanfaatkan sebagai musuh 
alami dalam praktek budidaya pertanian, bahkan beberap jenis dar kedua macam organisme tersebut sudah dikomersialkan formulasinya.

\subsubsection{Jamur}

Dari dunia jamur telah ditmeukan dan dimanfaatkan beberapa spesies dari genus tertentu, di antaranya Trichoderma, Aspergillus, dan lainnya.

Trichoderma adalah fungi yang bisa digunakan sebagai pengendali hayati berbagai penyakit baik yang disebabkan oleh jamur maupun bakteri pathogen, di samping memiliki kemampuan sebagai agensia biofertilasi bagai tanaman karena mampu memberi sumbangan nutria bagi tanaman [12-13]. Fungi ini menghasilkan: senyawa antibiotik dan toksin yang dapat menghambat berbagai jenis patogen peneyab penyakit tanaman [14]. Trichoderma mampu menghasilkan berbagai enzim yang dapat merusak dinding sel fungi patogen [15] dan secara lagsung menghambat patogen [16] dalam niche dan habitus yang sama. Senyawa ekstraselular yang dikeluarkan oleh fungi dalam ke lingkungannya terkait dengan karakter sebagai pengendali hayati jamur pathogen adalah enzimenim selulolitik yang dapat mendegradasi dinding sel dan bahan organic [17-18]. Kemampuan menghasilkan senyawa ekstraselular yang dapat berperan sebagai senyawa pengatur pertumbuhan tanaman seperti auksin 
dan turunannaya [18-19], menjadikannya sebagai agen biofertilasi unggul yang dapat menjamin kebutuhan nutrisi dan pertumbuhan tanaman sekaligus mengurangi penggunaan pestisida sintetik [20]. Hifa Trichoderma yang kontak dengan hifa Fusarium oxysporum dan melakukan parasitasi sehingga menghambat hingga $82,22 \%$ pertumbuhan pathogen secara in vitro [21].

Karakter utama Trichoderma sebagai agen biokontrol dan agen biofertilasi ini sangat diperlukan bagi upaya perlindungan tanaman, termasuk terhadap bibit dan tanaman muda tembakau. Namun demikian diperlukan jenis dan isolat fungi Trichoderma yang dapat memberikan respons positif bagi tanaman tembakau dalam meningkatkan ketahanan terhadap serangan pathogen.

Trichoderma sp. Tc-Jjr-02 merupkan salah satu isolate koleksi Laboratorium Mikrobiologi UMSIDA telah yang telah teruji efektif mengendalikan tanaman kentang [22], dan berbagai tanaman yang memilki kekerabatan dekat dengan tembakau yaitu dari famili solanceae seperti tomat dan sawi [23-24].

Kombinasi jamur Trichoderma viride yang berasal dari tanah supresif dan bahan organik dapat digunakan untuk mengendalikan penyakit layu fusarium pada pisang, sedangkan bila menggunakan bahan organik saja tidak berpengaruh nyata terhadap keterjadian dan keparahan penyakit [25]. 
Beberapa isolate jamur juga ditemuka bersama-sama dengan isolate bakteri yang hidu sebagai endofik di perakara tanaman jagung, ternyata efektif menekan patogen $F$. verticilloides dengan menggunakan metode dual culture [26], namun demikian membutuhkan uji lebih lanjut baik secara in vivo maupun di lapang agar layak komersialkan.

\subsubsection{Bakteri}

Seperti halnya pada jamur Trichoderma, pada beberapa jenis bakteri yang berptensi sebagai agen biokontrol juga memiliki kemampuan sebagai agen biofertilasi. Bakteri juga menghasilkan enzim-enzim selulolitik yang berperan dalam proses perobakan bahan organic di dalam tanah menjadi nutrisi bagi tanaman yang dibudidayakan.

Salah satu jens bakteri yang berpotensi dan sudah banyak dimanfaatkan sebagai alernatif pengendalian menggunakan bahan kimia sitentis dan saat ini banyak dikampanyekan oleh banyak phak adalah Bacilus subtiis.

Bakteri dari jenis ini dapat di peroleh di lingkungan pertanian, namun karakteristik sebagai agen biokontrol yang potensial dan efektivitasnya perlu diuji, mengingat spesies B. subtilis ini memiliki keragaman strain dengan spectrum keragaman keragaanya mulai yang bersifat sebagai agen biokontrol yang kuat hingga yang bersifat 
patogenik. B. subtilis B315 menghasilkan enzim amylase dengan aktivitas 0,802 unit/ml serta senyawa-senyawa kelompok alkana, aldehid, keton, asam karboksilat, ester, amina, dan amida, sehigga secara efektif menekan pertumbuhan Ralstonia solamacearum pada kentang [27].

Senyawa organik yang mudah menguap (VOC) yang dihasilkan oleh rhizobacterium pemacu pertumbuhan tanaman (PGPR) telah terbukti memiliki potensi untuk mengendalikan patogen tanaman, merangsang pertumbuhan tanaman, dan menginduksi ketahanan penyakit sistemik [28-30], serta meningkatkan ketersediaan N, P, dan Fe [31]. PGPR, atau produk turunan PGPR yang dihasilkan bakteri [32-33] biasanya memerlukan kontak fisik dengan bagian tanaman untuk merangsang pertumbuhan tanaman [34]. Senyawa perangsang pertumbuhan dan bersifat protektif dihasilkan oleh tanaman yang berintekasi dengan $B$. subtilis [35].

Pada bakteri B. subtilis yang berkarakter kuat sebagai agensia hayati yang menghasilkan bragam senyawa aktif secara biologi dengan spektrum pemanfaata yang luas secara agronomis dan industri pertanian [36-37]. Di samping sebagai biokontrol dapat ditunjukkan kemampuannya mengendalikan beberapa penyakit tanaman. Di lain pihak sejauh ini perlu diuji kepadatan populasi sel bakteri ini ketika diaplikasika 
dalam pengendalian penyakit; meskipun dalam Lampiran Peraturan Mentri Pertanian No 70/SR.140/10/2011 dinyatakan bahwa populasi bakteri sesuai standar mutu Bacillus subtilis dengan jenis bahan pembawa cair adalah $10^{8}$ CFU.mL ${ }^{-1}$.

Peneliti biasa melakukan eksplorasi untuk mendapatkan isolate bakteri efektif. Isolasi di perakaran akan diperoleh sangat banyak jumlah isolate, untuk kemudian dilakuakn pengujian daya hambat terhadap pathogen secara in vitro. Sebagai contoh hasil eksplorasi pada pertanaman cabe di beberapa daerah diperoleh 252 isolat rhizobakteri yang kemudian diuji terhadap satu isolat Phytopthora capsici; hasilnya hanya tiga isolate memiliki daya hambat yang cukup efektif [38].

\subsubsection{Organisme lain}

Pemanfaatan nematoda sebagai agen pengendali hayati pathogen jamur sudah tercatat dalam beberapa publikasi, namun demikian pemanfaata organisme ini tidak popular.

Pemanfaatn virus yang bersufat patogenik terhadap jamur dan bakteri juga belum banyak dikenal oleh masyarakat. Secara teknis sangat dimungkinkan memanfaatkan virus yang spesifik terhadap pathogen tertentu sebagai penyebab penyakit jamur dan/atau bakteri pathogen. 


\subsection{Pemanfaatan dan Formulasi}

Agensia biokontrol akan bermakan kalau sudah sampai tahap formulasi dan pembuktian kinerjanya di lapangan. Untuk itu kegiatan riset dan pengujian formulasi agen biokontrol menjadi sangat penting.

Dengan mengacu pada informasi tentang keunggulan spesies tertentu dalam mengendalikan pathogen penyakit, maka banyak peneliti mencoba melakukan eksplorasi bakteri sejenis pada lahan pertanian untuk mendapatkan islat indigen yang nantinya dapat dmanfaatkan bagi pengendalaian penyakit di lokasi di sekitar sumber inokulum agensia bionktrol itu diperoleh.

Dalam mencari isolat bakteri soil borne yang yang difokuskan pada bakteri yang secara morfologis berpenampilan sebagai $B$. subtilis. Lokasi pengambilan tanah sampel disuahakan di lahan pertanian.

Sebanyak $250 \mathrm{~g}$ tanah sampel dimasukkan dalam Erlenmeyer $1000 \mathrm{ml}$ yang berisi aquades sebanyak 500 $\mathrm{ml}$, kemudian diaduk merata dengan menggunakan magnetic stirrer selama 5 menit dan didiamkan 30 menit. Sebanyak $1 \mathrm{ml}$ suspensi yang telah didiamkan dan dilarutkan dalam tabung reaksi yang diisi $9 \mathrm{ml}$ aquades steril dan divortex; kondisi ini disebut pengenceran pertama $\left(10^{-1}\right)$. Selanjutnya dari suspensi dengan pengenceran $10^{-1}$ tersebut diambl $1 \mathrm{ml}$ dan dimasukkan ke tabung reaksi berisi $9 \mathrm{ml}$ aquades steril dan divortex 
disebut pengenceran $10^{-2}$. Langkah yang serupa dilakkan sampai pengenceran terakhir yaitu $10^{-4}$. Untuk media penumbuhan bakteri disiapkan Nutrient Agar (NA) yang dibuat dengan bahan yang terdiri dari sodium chloride $5 \mathrm{~g}$, peptone $5 \mathrm{~g}$, yeast extract $3 \mathrm{~g}$, agar-agar kering 20 g, dan akuades $1000 \mathrm{ml}$. Semua bahan dimasukkan dalam beaker glass dan ditambahkan akuades hingga $1000 \mathrm{ml}$ serta diaduk hingga merata dan dipanaskan selama 30 menit, selanjutnya diletakkan dalam botol media dan disterilisasi menggunakan autoklaf (1 atm, $\left.121^{\circ} \mathrm{C}\right)$ selama 30 menit. Untuk penumbuhan bakteri dari suspensi sampel, disiapkan media tumbuh dengan menuangkan media NA cair secaa aseptic ke dalam cawan petri di dalam inkas. Sehari berikutnya suspensi tanah hasil pengenceran terakhir sebanyak $0,5 \mathrm{ml}$ yang diambil dengan menggunakan disposible syringe disemprotkan ke permukaan media NA di dalam cawan petri dan diratakan. Setelah di diinkubasikan selama 24-48 jam, dilakukan pengamatan terhadap koloni yang muncul.

Identifikasi bakteri Bacillus subtilis. Identifikasi bakteri dilakukan dengan cara mengamati sifat morfologi koloni serta dilakukan pengujian sifat-sifat fisiologi dan biokimia. Beberapa langkah uji yang dilakukan adalah: (i) uji media selektif yaitu isolat bakteri hasil pemurnian di tumbuhkan pada media selektif (Media NA) dan diinkubasi selama 24-48 jam. Uji positif pada genus 
Bacillus subtilis jika koloni berwarna putih, berbentuk rhizoid, dan permukaan flat; (ii) uji $\mathrm{KOH}$ dilakukan untuk membedakan bakteri uji termasuk bakteri gram positif atau gram negatif. Suspensi bakteri diletakkan pada preparat jika tidak melekat pada jarum ose ketika diangkat menunjukkan karakteristik Bacillus subtilis gram positif; dan (iii) uji Soft Rot, dilakukan untuk membedakan bakteri patogen dan non patogen. Bakteri akan dioleskan pada bagian kentang dan diinkubasikan selama 24-48 jam untuk mengetahui ada-tidaknya pembusukan kentang busuk yang akan mengindikasikan karakteristik bakteri apakah besifat sebagai agensia biokontrol atau sebagai patogen. Pembusukan pada lempengan kentang tidak terjadi itu mwnunjukkan bahwa isolate $B$. subtlis yang ditemukan berpotensi sebagau agensia biokontrol.

Uji in vitro. Pengujian ini penting untuk memastikan kalau jamur atau bakteri yang ditemukan dan merupakan kandidat agen biokontrol. Propagul Isolat jamur kandidat biokokontrol yang diambil dari koloni dari media perbanyakan seukuran diameter $5 \mathrm{~mm}$ dihadapkan dengan propagul pathogen dengan ukuran sama. Selajutnya diinkubasi selama sekitar tujuh hari diamati tiap hari dan dilakuka pengukuran pertumbuhan koloni patogen yang tegak-lurus dengan pusat koloni agen biokontrol. Panjang pertumuhan koloni kemudian dibandingkan dengan pertumbuhan 
koloni patogen yang ditumbuhkan secara tunggal. Selisih panjang diameter jamur pathogen dalam kultur tunggal dengan dual culture (yang berhadapan dengan antagonis) dan dibagi dengan diameter jamur pathogen dalam kultur tunggal serta dikali $100 \%$ into menjukkan daya hambat atau persentase penghambatan. Agen biokontrol yang potensial adalah yang mampu menghambat setidaknya $60 \%$ pertumbuhan pathogen.

\section{Pelaksanaan pengujian meliputi persiapan} percobaan. Trichoderma $\mathrm{sp}$ isolat Tc-Jjr-02 yang digunakan dalam percobaan ini adalah koleksi Laboratorium Mikrobiologi Universtas Muhammadiyah Sidoarjo. Isolat fungi Trichoderma diperbanyak dalam medium PDA-chloramphenicole [39] dengan masa inkubasi 14 hari. Kultur isolat yang dipanen dihancurkan dan dicampur dengan air sehingga menghasilkan suspensi dengan kepadatan populasi $10^{8}$ $\mathrm{cfu} / \mathrm{ml}$. Isolat bakteri pathogen $R$. solanacearum yang digunakan untuk meguji kemampuan agen biokontrol diperbanyak pada media NA. Setelah empt hari masa inkubasi kultur dipanen dan dibuat dalam bentuk suspensi dengan kepadatan populasi spora aktif $10^{9}$ cfu $\mathrm{ml}^{-1}$. Untuk keperluan aplikasi masing-masing diencerkan dengan air akuadest steril menjadi $10^{7}$ $\mathrm{cfu} / \mathrm{ml}$ konidiospora isolat Tc-Jjr-02 dan $10^{8} \mathrm{cfu} \mathrm{ml^{-1 }}$ sel bakteri aktif $R$. solanacearum [40]. Masing-masing suspense ditempatkan pada beaker glass $500 \mathrm{ml}$; ada 
dua macam suspense yaitu yang mengandung spora aktif fungi Trichoderma dan bakteri pathogen serta satu beaker glass berisi air aquadest steril. Semua dlakukan dalam kondisi aseptik.

UJi In Vivo. Tahap beriktunya setelah lolos dari uji in vitro yang ditunjukkan dengan daya hambat yang cukup tinggi yaitu mengujinya pada kondisi yang hampir sesungguhnya atau dikenal juga sebagai uji in vivo.

Berikut ini salah satu contoh teknis kegiatan uji in vivo yaitu pada pengujian agen biokontrol Trichoderma asperellum terhadap pathogen hawar daun bibit tembakau yang dilakukan oleh penulis/peneliti UMSIDA. Jenis tembakau yang digunakan dalam perobaan ini adalah termasuk tembakau kasturi varietas Baleno yang biasa ditanam pada musim kemarau. Bibit yang sehat, hasil penyemaian biji tembakau pada media tanah steril selama dua bulan, dipilih dengan ukuran seragam dan tidak memiliki gejala nekrosis, lesion, dan/atau gejala penyakit lainnya. Sekitar 30\% bagian ujung akar dipotong dengan menggunakan pisau tajam dan steril. Akar yang ujung-ujungnya sudah terpotong/dilukai terebut dimasukkan ke dalam suspensi yang berisi spora fungi agen biokontrol dan spora bakteri pathogen atau aquadest steril sesuai perlakuan yang diinginkan selama 10 menit. Setelah akar tampak tidak basah lagi, maka bibit dipindahkan ke media tanam baru yang steril. 
Selanjutnya bibit dipertahankan pada kondisi persemaian dengan penyiraman denga air steril pada media tanam untuk menjaga kelembaban sesuai kebutuhan pertumbuhan bibit tanaman tembakau. Hasil uji in vivo menunjukkan bahwa T. asperellum mampu menghambat serangan penyakit yang disebabkan oleh bakteri $R$. solanacearum sekaligus memulihkan kesehatan bibit tembakau.

Formulasi. Setelah melewati uji in vivo dan layak sebagai agen biokontrol, mikroba ini perlu diformulasi agar mudah dibawa kemasannya dan mudah dalam aplikasinya. Untuk keperluan itu, maka dilakukan perbanyakan $B$. subtilis dengan menggunakan media tumbuh eksrak kedelai gula (EKG). Untuk membuat EKG sebanyak 1 liter memerlukan 200 gr biji kedelai yang sudah dicuci bersih direbus dengan 1 liter air aquades, Setelah mendidih kedelai ditiriskan, kemudian tambahkan 20gr gula pada air rebusan kedelai dan dipanaskan hingga larut menggunakan api kecil selama 5 menit. Kemudian ekstrak kedelai dapat dipindahkan pada botol penyimpanan dan siap disterilkan pada autoklaf selama 30 menit (1 atm, $\left.121^{\circ} \mathrm{C}\right)$. Setelah disterilkan masukkan isolat bakteri cair pada EKG sebanyak 2 botol untuk 3 liter EKG. Kemudian diaerator selama 3 hari untuk memperbanyak secara aerob. Selanjutnya suspensi fomula cari yang terbentuk siap 
digunakan aplikasi di lapang dan ata untuk percobaan lebih lanjut.

Bentuk formulasi dapat berpengaruh pada daya tahan dan agresivitas bakteri agen biokontrol. Pengujian formulasi agen biokontrol Pseudomonas fluorescens menunjukkan formula cair ,granul dan pellet lebih efektif dibansdingkan formula serbuka dalam mengendalikan penyakit layu pada cabai yang disebabkan oleh Fusarium sp. dan Ralstonia solanacearum [41]. Formula Bacillus thuringiensis TS2 dengan bahan pembawa gambut, tapioka, dan limbah padat tahu menunjukkan stabilitas agen biokontrol yang mampu mengendalikan penyakit pustul bakteri Xanthomonas axonopodis pada kedele [42]. Bahan pembawa serupa juga efektif mendukung keragaan $B$. subtilis dalam mengendalikan penyakit hawar daun pelepah jagung yang disebabkan oleh Rhizoctonia solani [43].

Agen biokontrol baik dari jenis jamur maupun bakteri dapat difrmulasi dalam bentuk pada. Biasanya dicampur dengan kompos, tepung sekam, atau bahan lain yang mudah dalam proses pengemasan. Dedak telah diuji keefektivannya sebagai media perbanyakan populasi spora Trichoderma [44]. Bahan organic tersebut disebut sebagai bahan pembawa (carrier agent). Pengujian untuk memastikan kepadatan popualasi formulasi higgga $10^{6}$ CFU.ml-1 (untuk jamur) dan $10^{8}$ CFU.ml-1 (untuk bakteri), maka dilakukan pengenceran 
(10-6 sampai 10-9) atau lebih encer lagi dan cairannya disempotkan ke media pertumbhan (PDA, NA, dan lainnya tergantung jenis mikroba) dan dihitung jumlah koloni yang muncul di tiap pengenceran. Selanjutnya akan diperoleh nilai akhir perkiraan populasi mikroba dalam formula tersebut.

Untuk keperluan komersial, maka teknologi formulasi dapat lebih dikembangkan, misalnya dengan menggunakan bahan yang lebih murah namun efisien dalam proses produksi dan sesuai bagi ketahanan propagul mikroba di dalam mikroba nantinya.

\subsection{Aplikasi Musuh Alami}

Pemilihan musuh alami haruslah didasarkan pada informasi ilmiah dan bisa dipatikan kesesuaian antara pathogen penyebab penyakit dan tanamannya dengan agensia biokontrol yang ingin diaplikasikan. Setidaknya pengguna membaca aturan penggunan pada label produk yang sudah diperjual-belikan di pasaran.

Beberapa isolate Trichoderma biasanya efektif untuk mengendalikan berbagai patogen pada berbagai tanaman. Namn demikian tingkat efektifvitasnya tidaklah sama. Bahkan mungkin untuk kasus terntentu treatment penggunaan agen biokontrol justru kurang efisien karena tingkat keberhasilannya rendah apalagi jka dibandingkan dengan aplikas pestisida kimia sintetis. 
Di lain pihak seringkali pengguna hanya memahami gejala serangan namun tidak tahu pathogen penyebab penyakitnya. Spekulasi dalam aplikasi agen hayati biontrol mungkin tidak disarankan mengingat tidak tersedia informasi tentang karakteristik penyebab penyakit. Berbeda jika kita tahu patogennya, maka pemilihan agen biokontrol sudah memiliki acuan.

Untk luasan lahan yang besar, seperti perkebunan misalnya, tentunya tidak boleh mengandung unsure spekulasi atau kira-kira jenis pathogen penyebabpenyakit yang akan dikendalikan. Untuk kasus demikian, maka diperlukan suatu melalui serangkaian uji yang disebut Postulat Koch [45] untuk memastikan jenis pathogen yang bertanggungjawab terhadap kemunculan penyakitnya. Pengguna dapat mengirim sampel tanaman segar ke Laboratorium terdekat yang menyediakan jasa pemeriksaan; beberapa kampus yang memiliki program studi Agoteknologi, Proteksi Tanaman, dan/atau prodi yang memiliki laboratorium Hama dan Penyakit atau sejenisnya yang dapat melaksanakan uji Postulat Koch tersebut.

Untuk aplikasi agen biokontrol bagi pengendalian pathogen soil borne yang biasanya menyerang perakaran, pangkal batang, hingga tajuk yang berdekatan dengan permukaan tanah, maka pemberian formulasi dalam bentuk seperti pemupukan sangat direkomendasikan. 
Untuk aplikasi Trichoderma yang juga memiliki kemampuan sebagai agen biofertilasi yang baik, maka aplikasinya dalam bentuk padatan yang diberikan di perakaran atau di lubang tugalan sebelum/menjelang tanam sangat disarankan. Trichoderma yang memproduksi senyawa ekstraselular berupa senyawa pengatur pertumbuan dan menghasilkan nutriri melalui pendegraasian bahan organic akan memberikan pemenuhan kebutuhan yang optimal bagi pertumbuhan tanaman meskipun tanpa pemberian pupuk kimia buatan. Tanaman meskipun tanpa pemberian pupuk kimia buatan. Sementara itu senyawa ekraselular yang berbentuk toksik dan enzim kitinase [46], akan membantu melindungi tanaman karena aktivitas dapat merusak dinding sel pathogen [47]. Kemampuan berkompetisi dalam memanfaatkan sumberdaya makanan dan ruang akan membuat pathogen tersingkir dan tidak mampu melanjutkan invasinya pada jaringan sel akar, pagkal batang, dan bagian lainnya [48].

Penyemprotan suspensi agen biokontrol pada bagian tubuh tanaman yang terinfeksi pathogen dapat terdeposit dan mampu bertahan di daerah luka sekaligus menekan pathogen. Trichoderma-PP1, Trichoderma-PP3, Trichoderma-AG2, Trichoderma-PYK3, Paecilomyces-PP6, Paecilomyces-PP7, Paecilomyces-AG4, Paecilomyces-PYK4, dan Aspergillus-PP2 mampu tumbuh dan bertahan pada buah cabai dan menekan penyakit 
antraknosa yang disebabkan oleh C. gloeosporioides antara 50-95,83\% [49].

Penggunaan kompos gambut dan janjang kelapa sati sebagai media formulasi bakteri Bacillus sp. BK17 ternyata menunjukkan keefektifan agen biokontrol tersebut dalam mengendalikan jamur patogen Sclerotium rolfsii dan $F$. oxysporum pada kecambah cabai [50]. 


\section{Pertanyaan Bab 4.}

1. Bagaimana mekanisme musuh alami mengendalikan patogen penyebab penyakit. Jelaskan, beri contoh yang Anda tahu!

2. Apa perbedaan agen biokontrol dan agen biofetilasi. Apakah suatu jenis jamur dan bakteri yang memiliki kemampuan menghasilkan enzim pendegradasi bahan organik dan menghasilkan metabolit yang dapat berperan sebagai senyawa pengatur pertumbuhan dapat dimasukkan sebagai agensia yang digunakan dalam progam pengelolaan penyakit tanaman? Jelskan.

3. Jamur dan bakteri yang biasa digunakan sebagai agen biokontrol sesungguhnya terdapat di lahan pertaian, tetapi mengapa mikroba efektif ini sering tidak berperan membantu melindungi tanaman dari serangan pathogen penyebab penyakit? Jelaskan. 


\section{BAB 5 \\ TEKNIK PENGAMATAN PENYAKIT}

Kegagalan dalam mengatasi serangan penyakit tanaman di antaranya disebabkan oleh kesalahan dalam mendeterminasi karakteristik penyakit. Pelaksana pengendalian tidak punya ukuran intensitas serangan yang seharusnya sudah diantisipasi. Lebih diperparah apabila gejala dan jenis penyakit tidak diketahui.

Kesalahan dalam menentukan intensitas gejala serangan yang bisa mewakili gambaran secara keseluruhan areal pertanaman yag dikelola merupakan hal yang umum terjadi. Seringkali intensitas serangan hanya diamati sepintas dan tidak representative. Pengamatan mungkin meluas meliputi hampr semua bagian area area pertanaman, namun cara penentuan posisi dan sampel pegamatan yang tidak efektif dan tidak efisien.

\subsection{Pengamatan Gejala Penyakit}

Sesungguhnya pengamatan penyakit untuk mendapatkan informasi utama mengenai gejala dan intensitas penyakit dibutuhkan pengetahuan yang cukup terkait gejala serangan penyakit.

Pengamatan penyakit bertumpu pada gejala serangan penyakit serta intensitas serangan dan kejadian peyakit 
pada areal pertanaman yang menjadi obyek pengelolaan atau pengamatan.

Dalam pengamatan gejala serangan penyakit, beberapa hal yang harus diperhatikan yaitu:

(i) Kerusakan tanaman, yaitu perubahan-perubahan fisiologis tanaman yang menyebabkan tanaman tidak memperlihatkan pertumbuhan dan aktivitas hidup yang normal dan ditujukan pada gejala pada sebagian atau seluruh bagian tubuh tanaman (daun, batang, cabang dan ranting, akar). Perubahan gejala dari satu waktu ke wakt berikutnya dapat dideteminasi dengan baik dan dapat diukur baik secara kualitatif dan yang terpenting ukuran kuantitatifnya;

(ii) Luka tanaman, adalah kondisi kerusakan yang menyebabkan menurunnya kapasitas tanaman untuk tumbuh dan produksi serta hilangnya bagian tanaman sebagai akibat adanya gejala serangan penyakit yang nilaiya dapa dinyatakan secara kuantitatif.;

(iii) Pengamatan bersifat langsung yaitu pengamatan gejala suatu penyakit secara langsung sehingga dapat diamati dan ditentukan kerusakannya. Pengamatan penyakit busuk Fusarium pada sawi puth ditujukan dengan mengamati gejala serangan pada seluruh bagian tajuk tanaman. Intensitas serangan diukur berdasarkan kriteria 
dan nilai skor yang sudah ditetapkan. Pada intensitas gejala penyakit yang sedang hinga mendekati berat sudah dipastikan tanaman tidak akan mampu menghasilkan produk panen, bahkan tanaman akan mengalami kematian. Sementara itu jika intensitas serangannya ringan sampai mendekati sedang, kerusakan dalam bentuk kegagalan panen dan kematian tanaman dapat dihindari dengan memberikan perlakuan pengendalian yang tepat;

(iv) Pengamatan bersifat tidak langsung yaitu pengamatan terhadap serangan busuk umbi kentang yang juga disebabkan oleh Fusarium. Pengamatan gejala harus lebih presisi karena mengamati kelayuan daun kentang sementara itu seluruh permukaan dau dan bagian tubuh tanaman di atas tanah tidak terdpa gejala apaun baik nekrosis, spot, busuk, dan lainnya. Biasanya criteria ditentukan dengan mengacu pada tingka kelayuan untuk memprediksi intensitas serangan pada umbi. Pada kasus ini umbi yang dimaksud adalah umbi bibit yang ditanam. Ketika umbi baru terserang pathogen, mungkin gejala di tajuk belum nampak di minggu keempat setelah tanam, namun satu minggu kemudian gejala lau mulai terlihat. Dalam kondisi ini harus sudah dlakukan tindakan pengendalian yang tepat. 
Untuk pengamatan ntensitas serang dn kejadian penyakit pelru diperhatikan apakah gejala penyakit yang tampak pada tanaman itu muncul ditanggungjawabi oleh satu jenis pathogen atau lebih dari satu jenis pathogen yang menyerang. Tentu akan berbeda di dalam member penilaian pada kedua macam gejala tersebut. Pengamat bisa membuat dan mengacu pada kriteria satu gejala dengan satu penyebab masing-masing atau kriteria satu gejala dengan dua penyebab. Semua bisa dilakukan, namun harus dengan pertimbangan ahli dan didasarkan juga pada pengalaman dalam pengematan gejala enyakit dimaksud.

\subsection{Teknik Pengambilan Sampel}

Keberhasilan melaksanakan assessment intensitas serangan penyakit sangat ditentukan oleh kualitas pengambilan sampel.

Kualitas pengambilan sampel dalam pengamatan penyakit tanaman sangat ditentukan oleh:

(i) Sifat dan ketrampilan petugas pengamat. Kecermatan dan ketrampilan/pengetahuan petugas akan menetukan kelayakan sampel yang diambil. Denan demikian total sampel yang diambl merepresentasikan kondisi umum areal pertanaman yang diamati; 
(ii) Keadaan lingkungan setempat; hal ini sering menjadi pembatas. Kondisi cuaca yang ekstrim seperti hujan yang tidak teratur, fluktuasi suhu, hembusan angin mungkin mengharuskan petugas perencama harus mengkompromikan antara pertimbangan kesehatan dan kebugaran surveyor dan kemudahan dalam pengamatan di samping efisiensi buaya dan efektivitas kerja;

(iii) Epidemi penyakitnya, apakah secara epidiemiologi penyakit yang diamati bersifat monosiklik atau polisiklik. Pada penyakit yang monosiklik mungkin lebih mudah dalam menentukan intesitas gejala serag, tetapi pada penyakit yang bersifat polisiklik, maka pertimbangan adanya gejala yang baru muncul di bagian lain tubu taaman harus menjadi pertimbangan.

Metode pengambilan sampel yang digunakan tidak mesti sama pada satu jenis penyakit dibadgnkan jenis penyakit lainnya. Setidakya ada tiga macam metode pengamatan penyakit yang serupa pada pengamatan hama, yaitu:

(i) Metode mutlak. Pada metode pengamat/surveyor akan mengamati seluruh populasi tanaman. Dengan demikian akan dihasilkan angka pendugaan populasi dalam bentuk jumlah individu per satuan unit permukaan lahan; 
(ii) Metode nisbi/relatif. Pada metode ini pengamat akan menentukan sejumlah sampel yan dapat merepresentasikan keadaanumum seluruh areal pertanaman. Dengan metode ini akan dihasilkan pendugaan populasi yang sulit dikonversikan dalam unit permukaan lahan, misal: spore trap (perangkap spora);

(iii) Metode indeks populasi. Pada metode ini pengamat hanya mengukur apa yang ditunjukkan akibat serangan, dapat berupa tanda serangan; dalam kondisi ini hasil yang diperoleh adalah luas serangan.

\section{Program Penyusunan Pengambilan Sampel.}

Berikut ini langkah-langkah dalam pengambilan sapel, yaitu:

(i) Penentuan unit sampel (satuan pengamatan): tiap unit punya peluang sama, ukuran stabil, dapat dikonversi ke unit area, mudah dikerjakan, efisien. Teknik pengambilan sampel bisa dilakukan secara diagonal. Penenuan unit sampel ditentukan tersebar secara merata di antara garis imajiner diagonal (Gambar 5.1). 


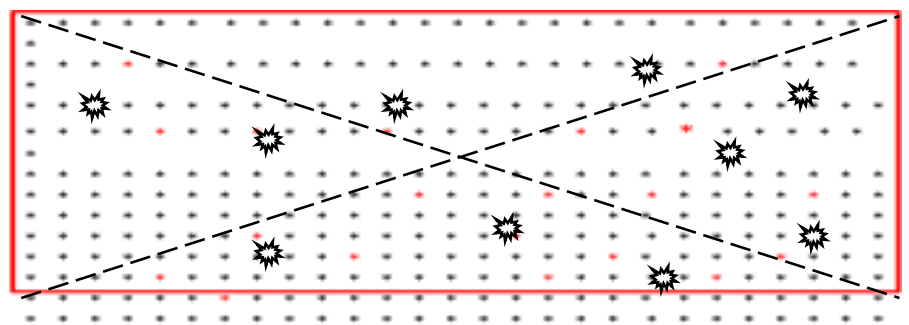

Gambar 5.1. Teknik pengambilan sampel secara diagonal; adalah unit sampel

(ii) Interval pengambilan sampel, dipertimbangkan jarak waktu pengambilan sampel tertentu;

(iii) Menentukan banyaknya atau ukuran sampel; digunakan prinsip seoptimal mungkin; jumlah sampel memadai dalam arti merepresentasikan keadaan umum di area pertanaman namun efiien dalam pelaksanaan;

(iv) Menentukan rancangan pengambilan sampel:

1. Acak sederhana (simple random sampling), bisa dilakukan dengan sampling sistematik;

2. Acak berlapis/bertingkat (stratified random sampling);

(vi) Melaksanakan mekanika pengambilan sampel.

Beberapa hal penting yang harus diperhatikan dalam teknik penilaian penyakit tanaman adalah:

(i) mengamati dan menentukan derajat keparahan;

(ii) membandingkan dan mendeskripsikan gejala serta tingkat keparahan;

(iii) menentukan skor atas gejala; 
(iv) menghitung tingkat serangan atau Indeks penyakit.

\subsection{Teknik Penilaian Intensitas Serangan}

Penilaian intensitas serangan suatu jenis tanaman akan berbeda dibandingkan jenis tanaman lainnya. Cara penilaian tanaman pangan berbeda dengan cara penilaian pada tanaman perkebunan. Di antara tanaman pangan dengan strata tajuk yang rendah juga berbedabeda. Perbedaan tersebut biasanya karena disebabkan oleh perbedaan kriteria dalam menentukan kategori atau tingkatan intensitas serangan yang didasarkan pada penampakan gejala penyakitnya

Apapun cara penilaian dan pengkategorian intensitas serangan itu semata-mata untuk mendapatkan nilai akhir yang dapat digunakan dalam menentkan langkah penanganan dalam program pengellaan penyakit.

Dalam melaksanakan penilaian pengamat harus memiliki konsistensi dalam menentukan kategori intensitas serangan berdasarkan gejala yang tanpak di lapangan yan tentunya mengacu pada standard atau kesepatakan, Dalam hal ini standard atau kesepakatan itu sebaiknya sudah teruji secara ilmiah, sehingga tiak menimbulkan kesalahan yang fatal dalam penilaian.

Untuk menjaga konsistensi, sebaiknya pengamat memahami gejala penyakit. Melatih diri untuk mendapatkan konsistensi dalam menilai juga sangat penting. Kalau sudah terlatih, maka di manapun lokasi 
pengamatan dan bagaimanapun kondisi area lokasi pertanaman tidak akan mempengaruhi ketepatan dalam menentukan pengkategorian gejala penyakit yang diamati.

Biasanya para ahli atau petugas terlatih di lapangan akan mengkategorikan intensitas serangan berdasarkan intesitas gejala berupa derajat atau intensitas kelayuan, nekrotitis, dan berbagai pertimbangan lain. Tanpa seragan termasuk kategori sehat diberi skor ' 0 ', serangan ringan, sedang, agak berat, dan berat/mati masing-masing diberi skor “1”, “2”, “3”, dan “4”. Di satu hamparan yang sama dan di waktu yang sama, kita bisa dapatkan kondisi tanaman dengan kategori yang berbeda seperti diilustrasikan pada Gambar 5.2. 


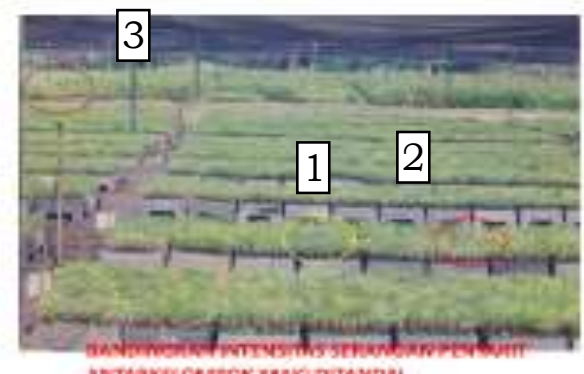

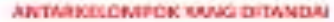

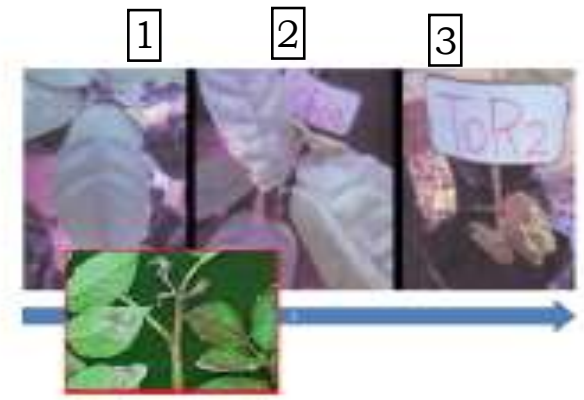

Gambar 5.2. Pengkategorian serangan penyakit bibit pinus (atas) dan tanaman kentang (bawah) dalam satu hamparan di waktu yang sama. Angka dalam kotak menujukkan skor keparahan gejala penyakit, lebih tinggi angkanya menunjukkan gejala lebih berat

Pengamatan kejadian penyakit. Untuk komoditas tertentu yang dimanfaatkan atau dikonsumsi misalnya dalam bentuk buah, maka yang perlu diketahui oleh pelaku usaha budidaya dan stake holder adalah informasi tentang kejadian penyakit. Dalam hal ini dilakukan penghitung jumlah buah atau tanaman terserang terserang dan jumlah seluruh buah atau jumlah seluruh tanaman yang diamati. Selanjutnya dihitung dengan menggunakan rumus [6]: 


$$
\mathrm{KP}=\mathrm{a} /(\mathrm{a}+\mathrm{b}) \times 100 \%
$$

Keterangan :

$$
\begin{aligned}
& \text { KP = Kejadian Penyakit } \\
& a=\text { Jumlah tanaman terserang } \\
& \mathrm{b}=\text { jumlah tanaman sehat }
\end{aligned}
$$

Keparahan penyakit. Penghitungan didasarkan pada data intensitas keparahan pada unit-unit sampel yang diamati gejalanya. Pengamat harus menentukan intensitas keparahan di lapangan mengacu pada standard atau pedoman scoring intesitas serangan.

Berikut ini contoh kategori gejala yang ditentukan pada tamanan kehutanan yaitu pada bibit pinus yang terserang hawar daun Pestalotia thea yang sesungguhnya biasa menyerang tanaman teh di berbagai daerah di Indonesia (Tabel 5.1)[11]. Pernyataan kategorisasi gejala akan berbeda pada bibit tanaman jenis yang berbeda misalnya pada serangan hawar daun kakao yang disebabkan oleh Phytopthora palmivora (Tabel 5.2)[51]. 
Tabel 5.1. Kriteria gejala hawar daun bibit dan/atau tanaman $P$. merkusii yang disebabkan oleh $P$. theae [11]

Skor Kriteria gejala

0 Tidak ada gejala hawar daun

1 Sampai 1/3 bagian tajuk dengan ujung-ujung dan/atau bagian tengah daunnya menguning

2 Antara 1/3-2/3 bagian tajuk dengan ujung-ujung dan/atau bagian tengah daunnya menguning dan/atau sampai $1 / 3$ bagian tajuk dengan ujung-ujung dan/atau bagian tengah daunnya coklat mengering

3 Lebih dari 2/3 bagian tajuk dengan ujung-ujung dan/atau bagian tengah daunnya menguning dan/atau sampai 1/3-2/3 bagian tajuk dengan ujung-ujung dan/atau bagian tengah daunnya coklat mengering

4 Lebih dari 2/3 bagian tajuk dengan daun-daun coklat mengering hingga tanaman mati

Tabel 5.2. Kriteria gejala daun bibit kakao berdasarkan luka hawar yang disebabkan oleh $P$. palmivora

Skor Kriteria gejala

0 Tidak tampak gejala hawar daun

1 Gejala hawar daun terbentuk di permukaan daun yang diinokulasi

2 Gejala hawar daun terbentuk dengan infeksi mulai melebar melampaui luas permukaan daun yang diinokulasi

3 Gejala hawar daun terbentuk dengan infeksi berkembang mencapai setengah luas permukaan daun

4 Gejala hawar daun terbentuk dengan hampir semua permukaan 
Nilai skala disubtitusi ke dalam rumus (5.2)[52]:

$$
\mathrm{IP}=\sum_{i=1}^{k=4}(\mathrm{in} i) \mathrm{x}(\mathrm{N} . k)^{n-1} \times 100 \%
$$

Dengan ketentuan:

IP = Indeks penyakit; $\mathrm{i}=$ nilai numerik (skor) bibit dan/atau tanaman dengan kriteri gejala serangan yang bersangkutan; $\mathrm{n} i=$ jumlah bibit dan/atau tanaman dengan kriteria gejala serangan yang bersangkutan; $\mathrm{N}=$ juimlah bibit dan/atau tanaman muda; dan $\mathrm{k}=$ nilai numerik (skor) tertinggi dengan kriteria gejala seragan terberat.

Rumus (5.2) tersebut dapat digunakan untuk menghitung dengan kategori terberat bernilai 5 atau di atasnya. Demikian juga dengan nilai $\mathrm{N}$ yaitu jumlah tanaman yang diamati dapat disesuaikan dengan kebutuhan pengamat. Nilai skor juga tidak harus berbentuk seperti nmoro urut atau deret hitung seperti mulai dari $0,1,2,3$, dan 4 , tetapi bisa juga dengan urutan 0 (sehat bebas gejala), 1 (sangat ringan), 3 (ringan), 5 (sedang), 7 (berat). Pemberian angka skor yang lain dari yang dicontohkan itupun dipersilahkan, namun tentnya degan pertimbangan yang logis dan mudah diimplementasikan.

Kategori bisa ditentukan secara berbeda dibandingkan kedua contoh di atas karena pertimbangan karakteristik tanaman dan tipe serangan pathogen. 
Namun apapun klasifikasi kategorinya, si pengamat harus menerapkan secara konsisten.

Contoh lain yang berbeda dari conth di atas, adalah dalam menentukan intensitas serangan blast pada malai padi gogo yang disebabkan oleh jamur Pyricularia grisae. mengacu pada IRRI, 2013 [53]:

$$
\text { PBS }=\frac{(10 \times \mathrm{N} 1)+(20 \times \mathrm{N} 3)+(40 \times \mathrm{N} 5)+(70 \times \mathrm{N} 7)+(100 \times \mathrm{N} 9)}{\text { Total }}
$$

dengan ketentuan

PBS = Panicles Blast Severity (intensitas keparah blast pada malai) adalah jumlah skor 1-9 yang masing dikalikan koefisiennya kemudian dibagi total malai yang diamati;

$\mathrm{N}=$ jumlah malai dengan skor 1-9

1 = Lesio (luka mengering) pada beberapa pedikel atau cabang sekunder

3 = Lesio pada beberapa cabang utama atau bagian tengah sumbu malai

$5=$ Lesio sebagian disekitar pangkal (node) atau ruas paling atas atau bagian bawah sumbu malai dekat pangkal

7 = Luka penuh di sekitar pangkal malai atau ruas paling atas atau sumbu malai dekat dasar dengan lebih dari 30\% biji-bijian berisi 
9 = Luka penuh disekitar pangkal malai atau ruas paling atas atau sumbu malai dekat pangkal dengan kurang dari 30\% butiran terisi.

\subsection{Pemanfatan Data Hasil Pengamatan}

Data Indeks Penyakit (intensitas serangan) digunakan untuk menentukan:

(i) ambang ekonomi atau ambang luka ekonomi;

(ii) memanfaatkan informasi harga dan data ambang pendapatan;

(iii) menentukan laju kehilangan hasil akibat serangan penyakit melalui model regressi;

(iv) waktu/saat aplikasi pestisida atau melaksanakan tindakan pengendalian lainnya;

(v) strategi pengendalian penyakit.

Pengalaman mengamati tingkat serangan dan hasil panen akibat adanya gangguan penyakit sesungguhnya dapat digunakan untuk mempredikssi kerusakan yang mungkin ditimbulkan jika pengendalian yang optmal tidak dilakukan. Jika suatu perusahaan besar (perkebunan atau budidaya tanaman produksi pangan) menemui kasus serangan penyakit, sesungguhnya tim proteksinya (atau tim $R \& D$ ) bisa melakukan pengamatan lebih lanjut untuk satu plot kecil yang lingkungannya terkendali untuk mengetahui berapa kehilangan hasil 
akibat intensitas serangan tertentu yang dipertahankan hingga panen.

Dimisalkan, setelah dilakukan pengamatan atas petak-petak contoh dengan intensitas serang yang berbeda-beda, pada saat panen diperleh data sebagai berikut:

\begin{tabular}{|c|c|}
\hline $\begin{array}{c}\text { X } \\
\text { Indeks Penyakit }\end{array}$ & Hasil panen (Kw/Ha) \\
\hline 0 & 80 \\
\hline 5 & 72 \\
\hline 10 & 65 \\
\hline 20 & 60 \\
\hline 30 & 58 \\
\hline 40 & 50 \\
\hline
\end{tabular}

Data tersebut dapat diolah dengan software Microfosot Excell, maka akan diperoleh model regresi indeks penyakit sebagai berikut

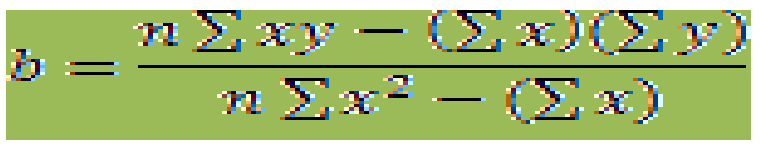

Dimana, $\mathrm{a}=($ Rerata $\mathrm{y})-(\mathrm{b} \cdot \operatorname{Rerata} \mathrm{x})$ atau potensi hasil padi pada saat tidak ada serangan penyakit

$$
\begin{aligned}
& \mathrm{Y}=\text { hasil panen padi }(\mathrm{kw} / \mathrm{ha}) \\
& \mathrm{b}=\text { laju kehilangan hasil }
\end{aligned}
$$

Maka diperoleh model: $\mathrm{Y}=39,8-0,17 \mathrm{x}$ 
- $\mathrm{a}=39,8$

- $\mathrm{b}=-0,17$

Model ini bisa dapat digunakan sebagai acuan relatif untuk memprediksi panen jika di perode yang sama di tahun berikutnya dijumpai itensitas serangan terntentu. Itu juga berarti bahwa petani dan pelaku budidaya dapat memutuskan untuk melakukan tindkan pengendalian yang maksimal bahkan mungkin pada saat terntu menggunakan pestisida kimia untuk menekan dan menghambat secara cepat laju peningkatan intensitas serangan penyakit.

Implikasinya adalah pelaksana budidaya dapat menentukan sampai pada tingkat intensitas berapa penggunaan pestisida kimia ditetapkan. Dengan mudah dapat dihitung proyeksi hasil panen yang dapat diselamatkan dan biaya pngendalian menggunakan pestisida. Jika hasil yang dapat diselamatkan pada sampai level intensitas seragan penyakit tetentu lebih besar dari pada biaya pengendalian, maka sebaiknya diputuskan untuk mengoptimalkan bekerjanya pengendali alami (nature control) yang ditangungjawabi oleh organisme antagonis indigen di lapangan dan/atau komponen lingkungan (cuaca dan sistem pertanaman) yang menciptakan kondisi yang menghambat patogen.

Untuk satu jenis tanaman seringkali tidak dapat digunaka kategori yang sama untuk fase pertumbuhan tanaman yang berbeda. Pada banyak kasus 
pengkategorian dan scoring pada fase bibit berbeda dengan fase tanaman deawasa atau pohon. Namun ada juga yang hampir sama dengan seikdit perbedaan. Gejala yang muncul pada tingkat semai Acacia crassicarpa Cunn Ex. Benth dengan derajat keparahan sedang tetapi ringan pada tingkat pancang, tiang dan pohon. Derajata keparahan penyakit menurun seiring bertambahnya usia [54].

\subsection{Determinasi Patogen}

Sub bab ini sebagai pelengkap pembahasan teknik pengamatan penyakit, meskipun sesungguhnya untuk level mahasiswa tahun terakhir dan peneliti penyakit harusnya sudah menguasai informasi jenis pathogen yang akan diamati gejala serangannya di lapang. Determinasi patogen bisa dilakukan sendiri oleh para peneliti dan mahasiswa yang akan melaksanakan penelitian dengan bantuan fasilitas laboratorium. Informasi hasil determinasi jenis pathogen yang gejala akan diamati sesungguhnya dapat diperoleh dari berbagai sumber ilmiah. Namun pengetahuan terkait determinasi dan karakerisasi jenis-jenis pathogen penting dibahas dalam sub bab ini.

Patogen yang bertanggung jawab terhadap kemunculan gejala penyakit dapat diketahui dengan melakukan beberapa cara dan prosedur: 
(i) Isolasi dan melihat lagsung morfologi koloni, hifa dna percabnagannya, dan sporanya kemudian dicocokkan dengan hasil publikasi atau buku yang memuat kunci determinasi. Satu contoh, dengan cara ini diketahui Pyricularia oryzae penyebab penyakit blas padi [55]. Karakterisasi berbasis morfologi serta uji gram, $\mathrm{KOH}$, dan produksi katalase dengan menggunakan metoe double layer pada media yeast peptone glucose agar (YPGA) dapat dideterminasi berbagai isolate Bacillus yang berkembampaun baik dalam menghambat $R$. solanacearum [56];

(ii) Melalui perunutan nukleotida gen. Metode penelitian ini meliputi pengumpulan tanaman sakit, ekstraksi RNA total tanaman, sintesis cDNA, amplifikasi DNA, visualisasi hasil reverse, transcription polymerase chain reaction ( $\mathrm{RT}-\mathrm{PCR}$ ), analisis perunutan nukleotida dan filogenetika menggunakan program BLAST [57-58]. Berdasarkan hasil RT-PCR menggunakan pasangan primer spesifik (TICV CP-F Bam dan TICV R-Hind) diperoleh pita DNA berukuran 792 $\mathrm{pb}$ dan diketahui bahwa pathogen penyebab klorosis tulang adalah virus Tomato infectious chlorosis virus (TICV) [59]. Untuk Trichoderma digunakan primer [60]: 
ITS 1 (5'-TCC GTA GGT GAA CCT GCG G-'3) dan ITS 4 (5'-TCC TCC GCT TAT TGA TAT GC-3'. Metode deteksi yang berbasis asam nukleat juga dilakukan untuk mendeteksi dan mendeterminasi virus mosaik kacang umum kacang (BCMV) dan mosaik Ketimun virus (CMV) [61]. Untuk menentukan pathogen, dilakukan deteksi fitoplasma jaringan tanaman kelapa yang bergejala sakit layu menggunakan teknik nestedPCR (nPCR); kloning dan sekuensing, serta analisis hasil sekuensing menggunakan RFLP in silico [62]. Ekstraksi RNA dilakukan menggunakan Xprep Plant RNA mini kit. Amplifikasi RNA dengan teknik RT-PCR, sekuensing dan analisis homologi dan filogenetik diketui jenis virus mosaic pada tanaman nilam yaitu CymMV [63], serta pada tanaman kacang panjang yaitu Bean common mosaic virus (BCMV) [64];

(iii) Menggunakan marka metabolit yang dihasilkan agen biokontrol. Untuk mengetahui islat rizobakteri indigenos dari tomat yang mampu mengendalikan Ralstonia syzigii subsp. indonesiensis dan meghasilkan senyawa Pemacu pertumbuhan dan hasil, maka determinasi dilakukan terhadap kemampuannya 
menghasilkan auksin dan enzim pelarut fosfat [65].

\section{Pertanyaan Bab 5}

1. Diketahui dari hasil penelitian tahu lalu diperoleh model yang menghubungan intensitas serangan degan hasil panen per hektar yaitu; $Y=39,8-$ 0,17 $\mathrm{x}$ (di mana $\mathrm{Y}=$ kuintal panen, $\mathrm{x}=$ intensitas seragan penyakit) Pada saat ini ketika intensitas serangan penyakit mencapai $5 \%(x=5)$, sementara itu biaya yang diperlukan apabila dilakukan pengendalian penyakit dengan menggunakan pestisida lengkap per hektar adalah setara dengan 7-8 kuintal panen. Bagamana menurut Anda apakah perlu pengendalian dengan kimia pestisida atau dibiarkan saja himgga panen? Jelaskan jawaaban Anda dengan argument yang komprehensif.

2. Silahkan pilih tanaman pertanian, horiktukur, atau perkebunan yang diasumsikan terserang peyakit tertentu. Coba buatkan table yang memuat kategori serangan dan deskripsinya serta angka skor yang memungkinkan.

3. Jelaskan bagaimana menurut Anda tekik pengamatan intensitas serangan penyakit. 


\section{BAB 6 \\ PRINSIP DAN PENYUSUNAN PROGRAM PENGELOLAAN PENYAKIT}

Sejak pertengahan 1960-an implementasi Green Revolution gencar di seluruh dunia yang ditandai dengan meningkatnya produki dan distribusi pupuk dan pestisida kimia sitetis. Kondisi ini juga didorong oleh meningkatnya tuntutan kebutuhan pangan. Di lain pihak di sebagain besar belaha bumi terjadi ketidakseimbangan antara pertumbuhan penduduk yang laju peningkatannya berdasarkan deret ukur dengan pertumbuhan produksi pangan yang laju peningkatannya berdasarkan deret hitung. Penggunaan pupuk kimia sintetis untuk meningkakan produksi sesuai kapasitas tanaman dan penggunaan kimia kimia toksik untuk melindugi tanaman dari organime penganggu tanaman yag sering kali menyebabkan kegagalan panen.

Penggunaan bahan kimia sintetis berbahaya yang makin massif dari waktu ke waktu, maka sekitar awal 1990an muncul kritik terhadap penggunaan pupuk dan pestisida kimia. Bahan buatan ini telah terbukti 
menimbulkan pencemaran lingkungan melalui pencucian nitrat, eutrofikasi, emisi gas rumah kaca dan penyerapan logam berat

Awal 2000an tampak sekali dirasakan dampak pestisida, maka mulailah dikampanyekan dan diimplemetasikan secara terbatas: pertanian organik, pengelolaan hama dan penyakit terpadu (Interated Pest Management, IPM), dan pengelolaan hara terpadu (Integrated Nutrient Management, INM), serta Sistem Pertanian Berkelanjutan.

Dampak pestisida. Semua pemangku kepentingan menyadari berbagai dampak penggunaan pestisida kimia sintetis toksik, yaitu:

(i) Terganggunya ekosistem (agroekosistem);

(ii) Rusaknya sumber plasmanutfah;

(iii) Resistensi patogen/hama terhadap pestisida;

(iv) Pencemaran tanah oleh bahan toksik dan logam berat;

(v) Menurunkan kesuburan tanah (biologi);

(vi) Meningkatnya biaya usaha tani.

Dari gambaran yang memunculkan ekhawatiran akan dampak pestisida, maka diperlukan pemilihan secara bijak metode pengendalian yang ramah lingkungan dengan mempertimbangkan berbagai prinsip pengendalian yang aman bagi manusia dan lingkugan namun memiliki kemampua untuk mendukung perwujudan prduksi tanaman sesuai potensi genetisnya. 


\subsection{Prinsip-prinsip Pengelolaan Penyakit}

Ada beberap prinsip yang harus menjaid pertimbangan dalam penyusunan program pengelolaan dan pelaksanaan pengendalian penyakit

\section{Pemanfaatan mekanisme ketahanan tanaman.}

Secara intrinsik sesungguhnya tanaman memiliki kemampuan untuk mengembangkan ketahanannya terhada serangan pathogen, meskipun tidak sedikit juga varietas tanaman yang memiliki ketahanan yang rendah, dan sering disebut juga tanaman rentan.

Banyak factor yang menyebabkan tanaman rentan atau level ketahanannya terhadap patogen tertentu rendah. Ketersediaan nutrisi yang rendah, cekaman lingkungan berupa intensitas cahaya yang tinggi, suhu tinggi, dan kelembaban udara yang tinggi misalnya dapat menyebabkan tanaman renatn terhadap serangan pathogen. Sebaliknya ketersediaan nutrisi, suhu dan kelembaban udara yang optmal serta aktivitas biologi organisme tanah yang menguntungkan berada pada kondisi optmal dapat menginduksi ketahanan tanaman atau mampu menopang tanaman dalam mengekspresikan potensi genetiknya untuk menahan 
serangan penyakiit. Menyeleksi genotipe tanaman yang tahan pathogen penyebab penyakit antraknosa cabai pada generasi kedua [66] misalnya adalah salah satu cara untuk mendapatkan tanaman tahan untuk selanjutnya digunakan dalam pengelolaan penyakit tanaman.

Pemanfaatan agensia biokontrol. Berbagai agen biokontrol telah berhasil divalidasi kemamapuan dan kapasitasnya; beberapa di antaranya sudah dikomersialkan dan masuk dalam kategori pestisida hayati.

Biopestisida adalah istilah untuk menunjukkan bahan yang digunakan untuk mengendalikan patogen penyebab penyakit adalah berasal dari organisme yang dalam hal ini adalah jasad renik dapat berupa fungi, bakteri, atau virus.

Jasad renik yang biasa digunakan sebagai bahan aktif pestisida disebut sebagai agensia hayati pengendali patogen penyebab penyakit atau lebih praktisnya disebut sebagai agen biokontrol.

Saat ini banyak penelitian yang bertujuan mencari dan mengembangkan agen biokontrol. Organisme dari phylum Eumycophyta (fungi) dalam 2-3 dekade terakhir banyak dipromosikan menjadi agen biokontrol terutama pada penyakit yang berifat soil borne (tular tanah).

Pemanfaatan teknik pengendalian secara agronomis. Metode ini sangat luas dan bersifat 
multidisiplin kajiannya. Ahli-ahli agronomi, ahli ilmu tanah, dan ahli ilmu pemuliaan bahkan pakar yang berkeahlian di luar pertanian telah bekerjasama dengan ahli fitopatologi dalam menciptakan teknologi yang menenarah pada pengendalan secara agronomis.

Aplikasi pestisida nabati. Mesti efektivitasnya tidak bisa menyamai efek pestisida kimia sintetts toksik, namun penggunaanya dalam skala terbatas dan dalam tingat serangan pathogen yang relative ringan patut disarankan untuk digunakan. Metabolit yang terkandung di dalam ekstrak tumbuhan selain efektif atau dapa menekan pathogen juga menandung berbagai senyawa yang bermanfaat bagi tanaman untuk memacu pertumbuhan misalnya. Namun demikia penggunnaannya juga harus mempertimbangkan efisiensi biaya pengandalian da perlindungan tanaman. Seringkali terjadi bahwa penyiapan pestiida nabati membutuhkan tenaga kerja lebih banyak dan bahan yang dihasilkannya terlalu sedikit bagi suatu program pengendalian yang konsisiten dan meluas.

Aplikasi pengendalian fisik dan mekanik. Aplikasi pengendalian ini kadang menjadi bagian dari tindakan agronomis dalam rangka menekan kenyaman dan aktivitas pathogen. Namun demikian perlakuan ini memerlukan penanganan khusus. Pada buddiaya anggrek dan bunga-bunga bernilai tinggi, tindakan mekanis berupa perempesan bagian tanaman yang 
begejala sakit lebih aman bagi kesehatan keseluruhan pertanaman.

Aplikasi pestisida kimia sintetis toksik; dilakukan bila tidak ada metode yang efektif untuk pegendlian penyakit dan penyakit akan menimbulkan kerusakan yang lebih parah jika tiak segera ditangani.

Pengintegrasian semua metode pengendalian. Penggunaan semua metode yang tersedia dan memungkinkan untuk diaplikasikan.

\subsection{Strategi Pengendalian Penyakit}

Pertimbangan Dasar Pengelolan Penyakit. Dasar pertimbangan yang digunakan dalam penentuan program pengelolaan penyakit adalah sebaai berikut:

1. Karakteristik Lahan dan ekosistem yang melingkupnya;

2. Riwayat/informasi gangguan hama-penyakit di area lahan dan sekitarnya;

3. Komoditas yang ingin dikembangkan;

4. Sumberdaya produksi yang dimiliki. Dalam hal ini adalah ketersediaan:

(i) agensia hayati potensial di lahan baik yang bersifat soil borne seperti Trichoderma, Aspergillus dll., air borne seperti: Metarrhizium, dan mikroba endofit;

(ii) potensi vegetasi penghara pestisida nabati dan "tabir" atau pelindung. Jika di area 
pertanaman tersedia, maka manfaatkan sebagai pestisida nabati seperti: papaitan, dan mimba. Jika memungkinkan manfaatkan tanaman yang bersifat penghambat penyebara pathogen namun tidak bersifat sebagai iang alternitf;pengalih perhatian

5. Anggaran biaya usaha dan proyeksi program pengendalian. Efisiensi dalam penggunaan biaya pengendalian menjadi pertimbangan penting.

6. Kemampuan teknis (metode dan penguasaannya). Dalam hal in harus tersedia metodologi yang memungkinkan untuk diimplementasikan. Meode pengendalia yang dipilih tentunya harus sudah dikuasai baik secara teknis maupun manajemennya;

7. Sumbedaya manusia pelaksana program. Dalam hal harus tersedia tenaga yang terlatif baik pelaksanaan program pengelolaan penyakit. Oleh karenanya perlu dipertimbangkan untuk melatih tenaga pelaksana program baik secara manajemen maupun teknik pelaksanaan aplikasi pengendalian penyakit.

\subsection{Konservasi Agroekosistem}

Dalam penyusunan program pengellaan penyakit, konservasi agroekosistem yang berkelanjutan harus lah menjadi prioritas utama. Keberhasilan pengelolaan 
penyakit dengan menujukkan produktivitas pertanaman yang tinggi dan bukti kesuksesan pengendalian penyakit mungkin menjadi tidak bermakna jika aspek konservasi diabaikan. Penggunaan pestisida secara massif dalam pengelolaan penyakit haruslah ditinggalkan.

Konservasi agroekosistem berarti mengindikasikan terpiliharanya keseimbangan relatif antarkomponen eksistem lahan pertanian dan sekitarnya yang mampu menjaga keberlanjutan produksi tanaman sesuai potensi genetic tanaman yang dibudidayakan.

Tuntutan yang tinggi untuk menciptakan beberapa varietas tahan selama periode waktu yang pendek merupakan salah satu indikasi bahwa telah terjadi perubahan virulensi pathogen sebagai kosekuensi mekanisme adaptasi untuk survivalitasnya. Dalam suatu pengujian ketahanan beberapa padi varietas unggul Ciherang, Inpari-4, -7, 8,-9) terhadap penyakit blast leher daun menunjukkan pathogen mampu mematahkan ketahanan pada sebagian varietas uji [53]. Hal yang sama juga terjadi pada pengujian ketahanan terhadap busuk buah pada beberap klon kakao [67].

Pada kawasan yang luas konservasi juga dapat melindungi galur-galur murni sebagai sumber bagi penciptaan tanaman resisten. Konservasi agroekosistem juga diharapkan dapat melindungi sumber plasma nutfah berbagai bakteri dan jamur potensial sebagai musuh alami yang efekif mengendalikan penyakit. 
Bahkan dapat tersedia jamur yang tubuh alami Nomuraea rileyi yang terrnyata efektif menimbulkan penyakit bagi Spodoptera frugiperda [68].

Sebagai gambaran terjaganya eksistensi seluruh komponen agroekosistem adalah, kita dapat melihat bahwa dengan kondisi cuaca yang sama, di kurun waktu yang sama, dan tanaman yang dibudidayakan dengan varietas yang sama, maka keberhasilan panen tahun kesatu relative sama dengan tahun kedua, ketiga dan seterusnya.

Kondisi itu mengindikasikan bahwa kehidupan biologi tanah yang kondusif bagi pertumbuhan dan produksi tanaman tidak terganggu dan.atau terdegradasi oleh kegiatan budidaya tanaman dan/atau oleh input dalam proses produksi.

Kondis ideal ini dimungkikan terjadi karena dalam budidaya khususnya pada program pengendalian terhadap OPT senantiasa memanfaatkan potensi sumberdaya lingkunan seperti agen biokontrol, mikroba efektif yang mampu membantu menyedakan nutrisi bagi tanaman, dan penggunaan pestisida kimia dilakukan secara terbatas dan diberikan pada saat tertentu bila terjadi potensi ledakan OPT. Biasanya dalam kondisi demikian komponen agroekosistemnya mampu melakukan pemulihan ketka terjadi cekaman yang sifatnya sementara. 


\subsection{Integrasi Metode Pengendalian}

Integrasi metode pengendalian adalah kata kunci dalam program pengelolaan penyakit tanaman. Haruslah dihindari penggunaan satu macam pengendalian sementara tersedia alternative metoe lain yang rmah lingkungan, murah, efisien, dan memungkinkan untuk dilaksanakan. Sejauh ini di banyak area budidaya seringkali hanya mengandalkan pestisida kimia sejak persemaian hingga menjelang panen. Cara demikian sudah terbukti tidak mengntungkan baik secara ekologi maupun secara ekonomi khususnya dalam jangka menengah dan jangka panjang.

Integrasi metode pengendalian berarti memanfaatkan beberapa metoda penelitian prioritas yang diaplikasikan secara terpadu sesuai dengan kondisi setempat dan memenuhi seluruh pertimbangan dasar pengelolaan penyakit dan pertimbangan konservasi agroekosistem.

Penggunakan varietas tanaman tahan. Metode ini memanfaatkan varietas yang sudah teruji tahan terhadap penyekit tertentu. Penanaman tanaman yang tahan terhadap serangan penyakit merupakan cara pengendalian yang efektif, murah, tidak berbahaya bagi lingkungan.

Ketahanan tanaman pada dasarnya ada dua macam yaitu: 
(i) Ketahanan genetik (bawaan), tanaman mampu untuk meregenerasi jaringan yang mati, atau selsel tanaman di bagian yang diinfeksi patog mengalam kematian yang cepat; sel-sel yang mati ini akan menghambat invasi pathogen, sementara sel-sel di belakang sudah melakukan regeneras dengan cepat. Pada jaringan yang sel-selnya membelah, maka aktivitas auksin meningkat dan dapat menghambat aktivitas enzim-enzim selulase daan petinase yang dikeluarkan oleh patogen [69]. Tanaman yang toleran meskipun terserang pathogen namun mampu meghambat perkembangan intensitas serangan bahkan menurunkan sekaligus mampu mempertahankan kapasitas produksinya;

(ii) Ketahanan ekologis (ketahanan semu): yaitu ketahanan tanaman yang disebabkan oleh factor lingkungan yang memungkinkan menampakkan sifat ketahanan terhadap serangan pathogen tertentu.

\section{Pengendalian kultur teknis (fisik-mekanik),}

Metode ini dilakukan di antaranya dengan memanipulasi lingkungan agar aktivitas patogen terhambat. Pemangkasan tanaman penaung, misalanya pada tanaman kopi untuk mengurangi kelembaban sehingga dapat mencegah serangan fungi Hemilia vastatrix patogen penyakit berbahaya. 
Pengendalian secara teknis agronimis. Beberapa teknis yang diimplementasikan adalah:

(i) Teknik Sanitasi dintaranya :memusnahkan tanaman atau bagia tanaman yang terinfestasi patogen dan menghancurkan tanaman atau bagian tanaman yang merupakan inang pengganti atau sumber infestasi pathogen penyebab penyakit;

(ii) Pola tanam: mengatur komposisi tanaman (tanaman campuran atau monokultur, tumpang sari), sehingga salah satu tanaman akan menjadi penghambat penyebaran penyakit tertentu dan sebaliknya;

(iii) Pengaturan jarak tanam; tindakan ini dapat menurunkan kelembaban sehingga menciptakan kondisi yang kurang mendukung bagi infeksi dan invasi pathogen;

(iv) Meningkatkan kesehatan atau vigor tanaman (meningkatkan ketahanan tanaman), misal dengan pemupukan, ZPT, dan penggunaan biofertilizer dengan bahan aktif adalah agensia biofertilasi.

Pengendalian dengan peraturan. Cara ini dilakukan dengan tujuan mencegah menjalarnya suatu hama atau mencegah masuknya hama ke satu daerah atau Negara dari Negara lain. Wujud dari peraturan/ undang-undang yang cukup efektif untuk tujuan 
tersebut adalah adanya karantina-karantina pertanian di pelabuhan atau lapangan terbang yang ditunjang oleh balai karantina.

Aplikasi biospestisida. Metode ini memliki prospek yang sangat baik di masa depan sebagai alternatif rekomendatif dengan bahan yang digunakan untuk mengendalikan patogen penyebab penyakit adalah berasal dari organisme yang dalam hal ini adalah jasad renik dapat berupa fungi, bakteri, atau virus.

Jasad renik yang biasa digunakan sebagai bahan aktif pestisida disebut sebagai agensia hayati pengendali patogen penyebab penyakit atau lebih praktisnya disebut sebagai agen biokontrol.

Saat ini banyak penelitian yang bertujuan mencari dan mengembangkan agen biokontrol. Organisme dari phylum Eumycophyta (fungi) dalam 2-3 dekade terakhir banyak dipromosikan menjadi agen biokontrol terutama pada penyakit yang berifat soil borne (tular tanah).

Pestisida selektif untuk pengendalian penyakit. Pestisida yang digunakan untuk pengendalian penyakit terdiri dari dua kelompok besar yaitu fungisida untuk pengendalian jamur pathogen penyebab penyakit dan bakterisida untuk pengendalian bakteri patogen penyebab penyakit. Sementara itu untuk pengendalian penyakit virus dulu disebut virisida. Namun mengingat prinsip bahwa penggunanan pestisida pada pengendalian penyakit virus berbeda dengan pestisida untuk jamur 
dan bakteri pathogen. Penangann virus biasanya diarah dengan mengendalikan serangga vektor penyakit, menggunakan varietas tahan dan penginduksian ketahanan tanaman, dan menggunakan teknik sanitasi dan teknik agronomis lainnya.

Berdasarkan susunan kimia bahan aktifnya, pestisida terbagi dalam dua golongan besar yaitu:

(i) Pestisida inorgonik, yaitu berbahan aktif senyawa in organik, biasanya dalam bentuk persenyawaan logam, contoh: tembaga oksiklorida, mankozeb (terdiri dari logam mangan dan seng) dengan merk dagang Dithane M-45. Aplikasi pestisida kimiawi, biasanya yang memiliki efek residual dan bekerja secara kontak sehingga bahan aktif dapat mencegah infeksi patogen; salah satu contoh bahan aktif yang sering digunakan adalah fungisida berbahan aktif mankozeb;

(ii) Pestisida Organik, yaitu pestisida yang berbentuk bahan organik baik yang alami maupun sintetik, fumigant (formalin, alkohol, karbondisulfida), senyawa tradisional (sabun, detergent), dan pestisida nabati (ekstrak tumbuhan seperti: lengkuas, kunir, cabe, lada, tembakau, dan lainnya. 


\subsection{Perancangan program pengelolaan Penyakit}

Dalam sub bab ini yang dibahas adalah perencanan program pengelolaan penyakit yang memiliki makna yang lebih komprehensif dibandingkan perencanaan program pengendalian. Dalam pengelolaan penyakit yang menjadi komponen pengelolaan bukan saja kumpulan metodologi penelitian tetapi juga segala tindakan, teknologi, dan metode yang tersedia dan memungkikan dapat dirangkum dalam satu program pengelolaan.

\subsubsection{Pembuatan rencana program.}

Rencana program sesungguhnya dapat disusun baik oleh kelompok tani maupun lemabag/badan usaha yang bergerak di bidang produksi pertanian di manapun. Dengan adanya perencanaan, maka proyeksi pembiayaan dan hasil dapat ditentukan dengan tepat. Tiap rencana pembiayaan atas pelaksanaan program akan masuk dalam anggaran biaya usaha tani secara lengkap.

Petani secara perorangan tentu tiak dapat diharapkan untuk membuat perencanaan yang baik, kecuali petani dimaksud memiliki skala usaha yang besar dan melibatkan banyak tenaga kerja. Namun demikian kiranya kelompok tani dapat mengkordinasikan seluruh rencana dan pelaksanaan kegiatan budidaya di dusun/pedukuhan setempat untuk 
membiaskan membuat perencanaan program pegelolaan penyakit.

Waktu dan tempat. Perencanaan harus memuat waktu dan periode program diterapkan; tempat atau lingkup area kerja harus dinyatakan secara lengkap. Dari sisi luas cakupan area, sesungguhnya ukuran satu dusun yang dikelola satu kelompok tani itu sagat ideal bagi implementasi program, akrena tidak terlalu kompleks dan interaksi di antara anggota cukup intensif.

Komoditas yang diusahahakan. Semua jenis komoditas yang diusahakan dinyatakan secara jelas termasuk jenis varietas dan karakteristiknya. Mengikuti informasi ini adalah luas tanaman untuk jenis tanaman dan anggota/petani pelaksananya.

Rencana dan proyesi produksi tanam. Bagian ini adalah pernyataan/uraian detail dari komoditas yang direncanakan diusahakan. Rencana program idealnya dibuat satu tahun. Dengan demikian akan diperoleh siklus dan pergiliran tanaman. Dalam satu Poktan boleh jadi tidak seragam dalam penanaman satu jenis komoditas untuk suatu kurun waktu tertentu. Informasi yang jelas akan mempermudah dalam penyusunan straegi pengendalian nantinya.

Pertimbangan program. Berbagai pertimbangan yang perlu dinventarisir dan dinyatakan dalam perencanaan adalah: 
(i) Tujuan usaha tani. Harapan dan target pribadi harus dapat dipadukan hingga memperkuat tujuan usaha tani kelompkok. Dalam hal ini sangat perlu diskusi yang cukup mendalam di anatara anggota kelompok. Untuk perusahaan (usaha kecil, menegah dan besa) tentu ini bukan masalah, karena sudah memiliki tujuan yang jelas dalam anggaran dasar dan angaran rumah tangganya. Tujuan bisa diubah/disesuaikan secara lebih mudah dibandngkan kelompok tani;

(ii) sumberaya manusia. Diperlukan pelatihan lapangan yang dibibing oleh narasumber (dinas setempat atau ahli/dosen dari perguruan tinggi pertanian);

(iii) karakteristik lingkungan, termasuk di dalamnya adalah potensi serangan peyakit dan daya dukung lngungan agroekosistem bagi usaha produksi. Jika di daerah tersebut kecepatan anginnya relative tinggi yang dapat mendorong kemudahan dalam penyebaran seranga vektor penyakit, maka secara gotong royong dianggarkan penanaman tumbuhan penahan angin (bamboo) serta tanaman pohon yang cepat tumbuhnya dan bertajuk rapat;

(iv) Potensi pasar, dengan demikian anggota kelompok tani sebaiknya menyesuaikan dengan 
potensi permintaan pasar akan komoditas terntentu;

(v) Modal kerja. Banyak di antara anggota kelompok yang memiliki sumbr dana yang minim. Untuk itu kelmpok dapa megembangkan koperasi di tingkat Poktan atau di tingkat desa (Gapoktan). Saat ini mendirikan koperasi dan usaha kecil sangat dipermudah oleh Negara. Untuk itu kelompk harus memanfaatkan peluang ini.

(vi) Narasumber. Sangat diperlukan baik ahli yang dapat membimbing dalam teknis pengendaian penyakit, maupun narasumber yang akan membimbing dalam pengelolan keuangan dan pengelolaan usaha/koperasi. Narasumber dapat diminta dari dinas terkait dan dari perguruan tinggi terdekat, sera LSM yang representative;

\section{Metode dalam pengelolaan penyakit tanam.}

Kelompok atau lembaga usaha harus menginventarisir dan memntukan metode pengendalian dan tindakan lainnya dalam program pengelolaan penyakit. Tidak semua metode pegendalian digunakan, tetapi pilih yang sesuai dan dibutuhkan dalam rangka perlindungan tanaman. Selain iitu berbagai tindakan yang secara tidak langsung mengendalikan peyakit juga harus dinyatakan masuk dalam perencanaaan kegiatan. 
Inventarisasi dan penyediaan peralatan dan bahan. Ketika metode pengendalian sudah ditentukan untuk disipakan, maka berbagai kebutuhan peralatan dan bahan harus didata dan dimasukkan dalam perencanaan. Hal ini juga menyangkut penentuan biaya yang diperlukan untuk pengadan peralatan dan bahan.

Penyususnan langkah kegiatan. Semua langkah kegiatan dimulai dari persiapan bahan dan peralatan pengendalian termasuk kegiatan penunjang, pelaksanaan monitoring, pelaksanaan aplikasi perlakuan, pengumpulan data tingkat serangan, hingga penanganan pasca panen harus dinyatakan secara jelas dan mudah dipaham oleh seluruh angota kelompok.

\subsubsection{Monitoring dan evaluasi}

Monitoring serta Pengumpulan dan analisa data. Kegiatan ini mungkin tidak popular di kalangan petani tradisional, namu di masa depan kegiatan ini akan disadari sanga penting dan menentkan keberhasilan usaha tani di masa berikutnya. Pada sekitar tahun 1995-1998, pemerintah begitu gencar menekankan pentingnya monitoring hama dan penyakit, karena data yang diperoleh akan menjadi pertimbangan penting dalam mengambil keputusan tindakan pengendalian khusustekait aplikasi pestisida kimia. Saat itu banyak kelompok tani yang dilatih melalui sekolah lapang agar memiliki ketrampilan dalam monitoring di antaranya 
ketrampilan menentukan intensitas serangan dan memanfaatkan usuh alami. Data yang diambil bukan saja intesitas dan luas seragan, tetapi juga berisi tentang catatan atas semua kejadian penting, serta luasan panen, total panen per komoditas, dan perubahan harga jual komoditas.

Evaluasi. Kegiatan evaluasi sebaiknya tidak hanya dilakukan di akhir musim tanam dan di akhir tahun, tetapi juag secara berkala dilakuakn evaluasi. Evaluasi berkala ini penting untuk mencari tahu dan mendalami kondisi yang terjaid di lapangan. Hasil evalusi jaka pendek ini bahkan sangat menentukan keberhasilan pegelolaan program. Cuaca selalu berfluktuasi terkadang di laur perkiraan, begitu juga lonjakan intensitas seragan dan keparahan penyakit bisa terjadi di laur perkiraan, Untuk itu evalusi yang melibatkan ahli/narasumber perlu dilakukan untuk mencegah kerusakan lebih lanjut bahkan untuk memulihkan kedaan secara cepat, mengingat kesimpulan atas terjadi kejadian luar biasa tersebut akan mempercepat proses penyesuaian dan pengambilan keputusan tindakan pengendalian tertentu yang tepat. 


\section{Pertanyaan Bab 6:}

1. Sebutkan dan jelaskan pertimbangan dalam penyusunan program pengelolaan penyakit? Jelaaskan menurut Anda adakah perbedaan dalam perencanaan program antara kelompok tani dan perusahan perkebunan dalam penyusuannya?

2. Konservasi agroekosistem sangat penting dalam program pengelolaan penyakit. Jelaskan maksudnya. Berlah juga contoh tndakan yang bersifat megkonservasi agroekosistem!

3. Jelaskan lagkah-langkah dalam penyusunan program pengelolaan penyakit tanaman! 


\section{BAB 7 \\ APLIKASI PENGELOLAAN PENYAKIT}

Pengendalian penyakit dalam rangka perlindungan tanaman dari gangguan patogen penyebab penyakit haruslah mempertimbangkan beberapa aspek yang sebagain merupakan bagian dalam tinjauan agribisnis, yaitu:

(i) Kuantitas produksi yang ingin dicapai dan yang memungkinkan secara potensi genetis tanaman;

(ii) Kualitas produksi, yaitu standard kualitas yang ingin dicapai sehingga panen memiliki nilai keekonomian yang layak dan memberi keuntungan;

(iii) Harga produk yang mengacu pada harga yang wajar atau harga pasar;

(iv) Biaya produksi yaitu semua biaya dan/atau investasi yang dikeluarkan dalam rangka produksi tanaman dan/atau hingga hasil panen sampai ke pihak pembeli;

(v) Penghasilan dan keuntungan usaha tani yang sudah ditetapkan; oleh karenanya tindakan pengendalian mungkin tidak dilakukan sejak dini jika diperkirakan usaha taninya tidak memberi keuntungan. 


\subsection{Pengelolaan Penyakit Tanaman Pangan-Horti}

Pada pengelolaan penyakit tanaman pangan yang terdiri dari padi, jagung, dan kedele sejauh ini di Indonesia dan di berbagai Negara lebih banyak mengandalkan pada keampuhan pestisida. Ada kegamangan petani jika peggunaan fungisida dirasa kurang. Fakta banyak membuktikan sebagaimana kurangnya aplikais pupuk kimia, begitu juga kurang aplikas pestisida kimia telah munjukkan produksi tanaman yang rendah per sauna luas area panen.

Pengendalian ditujukan pada inang. Di beberapa kelompk tani memang sudah menggunakan varietas tanaman yang dinyatakan tahan patogen tertentu oleh lembaga terkait. lembaga produsen dan pensertifikasi benih tersebut telah melakukan pengembangan strainstrain tanaman yang resisten (tahan) terhadap serangan patogen melalui hibridisasi atau seleksi tipe-tipe resisten; cara ini termasuk dalam kajian ilmu pemuliaan tanaman.

Pengendalian penyakit dengan mengunakan tindakan yang ditujukan terhadap tanaman inangnya, dilakukan dengan beberapa cara yaitu:

(i) Menciptakan atau menyiapkan tanaman yang kebal (resisten), yaitu dengan jalan menanam jenis tanaman yang resisten terhadap penyakit. 
Untuk mendapatkan jenis resisten dapat dilakukan dengan seleksi di lapangan atau dengan perkawinan silang ataupun dengan penyambungan (grafting) atau penempelan (okulasi);

(ii) Menggunakan tanaman yang toleran, yaitu dengan cara menanam tanaman yang dapat menyembuhkan diri atau menganti yang rusak karena serangan suatu patogen;

(iii) Menggunakan tanaman yang hipersensitif, yaitu dengan menanam jenis tanaman yang sangat peka bila diserang pathogen; sel-selnya yang diserang akan segera mati sehingga petogen ikut mati pula;

Memanipulasi lingkungan. Cara lain dlakukan dalam rangka melindungi tumbuhan terhadap perkembangan penyakit yang dilakukan dengan cara memanipulasi lingkungan seperti perlakuan fisis dan biologis. Pengendalian penyakit tanaman dapat ditujukan langsung pada sasarannya yaitu: patogen (terhadap penyebarannya), tanaman inangnya, dan keadaan tempat hidup tanaman atau penyebabnya.

Secara fisik kelembaban tanaman bisa dikurangi dengan mengatur jarak tanam menjadi lebih besar namun populasi tanaman dan prduktivitasnya per satuan lahan dapat dipertahankan, 
Penggunaan musuh alami baik dalam bentuk aplikasi aen biokontrol yang sudah diformulasi baik padat maupun cair yang dapat disemprotkan atau ditebar ke pertanaman merupakan cara yang efisien dan ramah lingkungan. Biopestisida $B$. subtilis telah terbukti mampu mengendaliakn penyakit hawar pelepah dan upih daun jagung yang disebabkan oleh $R$. solani [70]. Perlakuan benih dengan delapan jenis formulasi biopestisida B.subtilis (TM4, TM3, BNt4, BNt5, BNt6, BNt8, BJ6, dan TLB1) berhas1 menekan tensitas serangan embun tepung yang disebabkan Peronosclerospora philipinensis pada tanaman jagung [71].

Penggunaan pestisida nabati; saat ini telah banyak dikembangkan dan sudah membuktikan efektivitasnya, meskipun dalam penggunaan skala luas yang melingkup lahan yang luas memerlukan kajian dan pengujian lebih lanjut. Yang sudah cukup dikenal di masyarakat adalah penggunaan ekstrak bawang merah untuk mengendalikan serangan penyakit yang disebabkan leh jamur pathogen [72].

Pemupukan yang berimbang dan sesuai kebutuhan tanaman serta mempertimbangkan tingkat da karakteristik kesuburan tanah merupakan faktr penting dalam keberhasila pengelola penyakit tanaman. Pemupukan fosfat yang tinggi tidak akan bermanfaat ketika megabaika $\mathrm{pH}$ tanah. Sering terjadi ketersediaan 
$\mathrm{P}$ rendah di banyak lahan di Indonesia akibat mismanagemten kesuburan tanah. Pada kasus yang dmeikian aplikasi bakteri Pseudomonas yang teruji mampu membantu melepaskan $\mathrm{P}$ terikat justeru menjadi sangat penting dalam pengelolaan penyakit. Ketersediaan $\mathrm{P}$ yang optimal akibat kerja bakteri plarut fosfat akan memberi kecukupan nutrisi sentral bagi tanaman; pada akhirnya kondisi ini akan meningkatkan ketahanan tanaman terhadap serangan penyakit. Formulasi isolate $P$. fluorescent PF-122 dengan bahan pembawa pupuk organic diaplikasika sebagai pupuk hayati (biofertilizer) yang dapat meningkatkan pertumbuhan dan produktivitas tanaman [73].

Pengendalian terhadap patogen. Pengendalian yang ditujukan kepada patogen adalah tindakan untuk mencegah penyebarannya, yaitu meliputi:

(i) Sanitasi, yaitu membebaskan lapangan dari penyebab penyakit (patogen), misalnya dengan mengadakan penyemprotan dengan fungsida atau udara panas pada tanah;

(ii) Karantina, yaitu dengan penerapan peraturan karantina di mana tumbuhan dan atau bagian tumbuhan harus diperiksa dalam rangka untuk mendapatkan sertifikat fitosanitari yang mengizinkan barang dan atau tumbuhan dapat masuk (untuk impor) atau keluar (untuk ekspor). Karantina ertujuan mencegah penyebaran atau 
penularan dari suatu penyakit dari daerah (pulau atau Negara) ke daerah lain, dengan jalan melarang keluar masuk suatu tanaman atau bagia dari tanaman (kayu, biji, dan lain-lain) yang ada kemungkinan untuk membawa suatu patogen atau membersihkan dahulua (bila mungkin) dari patogen dengan menggunakan fungisida;

(iii) Aplikasi pestisida ketika tampak potensi terjadinya epidemic penyekit tertentu atau intensitas gejala serangan sudah mencapai level yang mengkhawatirkan akan memeunculkan kegagalan panen dan menimbulkan kerusakan yang meluas. Pada tingkat yang membahayakan, eradikasi secara terbatas di lahan dapat dilakukan dan sebaiknya hanya dengan satu kali aplikasi. Eradikasi dimaksud adalah memusnahkan patogen bersama tanaman inangnya atau dapat pula dengan memusnahkan inangnya sama sekali atau pemusnahan patogen dengan menggunakan fungisida. Di lain pihak fakta banyak ditemukan bahwa pengunaan bahan kimia sitentis sering menujukkan efektivitas yang rendah, menimbulkan resistensi pestisida, mengancam kehidupan organisme bukan sasaran dan pencemaran lingkungan [74]. Pendekatan menggunakan peramalan penyakit berdasarkan pebgimplementasian model epidemi dapat 
membantu menentukan waktu aplikasi fungisida. Di saming itu pengalaman petani dan pembudidaya di lingkungan areal pertanian dan di tempat lain pada komoditas yang sama perlu digunakan sebagai pertimbangan dalam mengambil keputusan penggunan pestisida kimia. Ketika intensitas serangan sudah menurun dan kesehatan tanaman sudah pulih, maka pemanfaatan secara maksimal metode pengendalian non pestisida kimia perlu dilakukan.

\section{Pengendalian yang ditujukan kepada inang dan}

tanaman. Aplikasi dengan bahan nabati atau pestisida nabati mulai banyak dikembangkan. Aplikasi ini secara langsung ditujukan untuk menekan patogen sekaligus secara tidak langsung memperkuat ketahanan tanaman. Limbah kacang mete juga dapat digunakan untuk mengendalikan penyakit dapat menurunkan kejadian penyakit dan memperlambat masa inkubasi Cowpea mild mottle virus (CPMMV) dengan cara menyemprotkannya pada permukaan daun kedele. Campuran minyak cengkeh dan ekstrak biji mimba dapat mengendalikan penyakit karat (Phakopsorapachyrhizi) pada kedelai [75].

\subsection{Pengelolaan Penyakit Tanaman Perkebunan}

Dalam pengelolaan penyakit tanaman perkebunan dibahas juga pengelolaan pada sistem agroforestri yatu 
suatu kegiatan budidaya tanaman yang didintegrasikan dengan tanaman kehutanan.

Tindakan pengendalian yang ditujukan pada tempat tumbuh atau di mana terjadi interaksi antara inang dan patogen; dalam tindakan ini juga termasuk memodifikasi komponen ekosistem atau komunitas tanaman di area tempat budidaya atau tempat dilakukannya kegiatan produksi.

Beberapa tindakan yang memodifikasi dan atau memanipulasi lingkungan tempat tumbuh adalah meliputi:

(i) Membuat tanaman campuran yaitu dengan mengatur komposisi, jarak tanaman, dan pemilihan jenis campuran sehingga dapat dihasilkan tanaman yang tahan terhadap penyakit;

(ii) Mengatur jarak tanam dari tegakan sedemikian rupa sehingga menghasilkan keadaan yang merugikan terhadap kehidupan patogen;

(iii) Melakukan penjarangan atau pemotongan/pemangkasan tanaman yang sakit atau terancam sakit agar dapat menghasilkan kondisi tanaman yang tidak disenangi patogen misalnya mengurangi kelembaban di bawah tajuk sehingga dapat menghambat infeksi patogen;

(iv) Mengatur naungan terutama pada naungan persemaian agar intensitas sinar matahari masuk 
dan kelembaban udarapun dapat diatur, hingga patogen tidak menyukainya;

(v) Pergiliran tanaman yaitu dilakukan dengan mengadakan pergiliran jenis tanaman sehingga patogen yang ada pada suatu waktu tertentu akan hilang inangnya hingga patogenpun ikut mati, tertekan, atau tereliminasi;

(vi) Mengatur drainase atau aliran air seperti selokan/parit dan saluran irigasi sehingga maka kelembaban udara yang relatif tinggi sebagai akibat genangan air dapat dihindari; hal ini akan mengurangi serangan patogen.

(vii) Aplikasi agensia hayati. Perkebunan sawit sudah banyak yang memanfaatkan fungi Trichoderma sebagai agensia hayati untuk mengendalikan pathogen soil borne yang biasa menyerang perakara dan pagkal batang yang menyebabkan kematian tanaman. Dalam keadaan tingkat serangan yang ringan atau pada saat tanam sebaiknya digunakan agensia hayati seperti Trichoderma sebaga upaya untuk perlindungan tanaman. Mengingat peran Trichoderma juga dapat sebagai agen biofertiliasi [76-77], maka aplikasinya sebagai pemupukan sangat disarankan. Hal yang sama dapat dilaksanakan di berbagai macam dan berbagai kondisi perkebunan dengan memanfaatkan agensia hayati 
apapun yang sudah teruji efektif mengendalika pathogen. Jamur ini juga dapat digunakan dalam pertanian dengan system agroforestri untuk mengendalikan busuk hitam buah kakao [67]. Kegiatan aplikasi agensia hayati dapat diintegrasikan dengan pemupukan. Beberapa isolate agen hayati Trichoderma bahkan selain melindungi tanaman dari ganguan pathogen juga mampu mendukung pertumbuhan tanaman pada tanah salin[78], melindungi tanmaan dan memacu pertumbuhan anaman [79];

(viii)Aplikasi pestisida nabati. Penggunaan bahan kimia alami yang berasal dari ekstrak tanaman perlu dipertimbangkan untuk menjadi bagian dalam pengelolaan penyakit perkebunan. Berbagai siolat kimia yang terkandung dalam ekstrak bawang merah misalnya telah diyakini dapat menekan jamur pathogen [80] di samping dapat memberi manfaat mensuplai fitohorman alami bagi tanaman. Penggunaan ekstrak gambas (Luffa acutangula) yang disemprotkan pada permukaan daun ternyata dapat menekan seranga penyakit Squash Mosaic Virus (SqMV) pada tanaman jenis yang sama [81].

(ix) Pemupukan yang seimbang, juga menjadi bagian penting dalam pengelolaan peyakit tanaman. Tanaman yang tercukupi kebutuhan nutrisinya 
akan memiliki kemampuan untuk meningkatkan ketahanannnya terhada serang penyakit. Penggunaan pupuk organik sangat disarankan, karena selain menyediakan nutrisi yang lengkap bagi tanaman juga mendukung pertumbuhan agen biokontrol di dalam tanah [25]. Pemberian bahan organic $20 \%$ (v/v) dapat mengendalikan penyakit busuk akar tanaman duku (Lansium domesticum) yang disebabkan oleh $P$. palmivora sekaligus meningkatkan ketersediaan $\mathrm{P}, \mathrm{K}, \mathrm{Ca}$, $\mathrm{Mg}$, dan $\mathrm{Zn}$ bagi tanaman [82];

(x) Aplkasi pestisida kimia. Sama seperti pengaplikasian pestisida pada tanaman pangan, haruslah mengutamakan integrasnya dengan beberapa metode lain dan digunakan apabila cara lain urang efektif pada saat itu, Selain itu aplikasi pestisida kimia sintetis sifatnya ingin menekan pathogen sampai pada level tertentu di mana komponen pengendalian non pestisida kimia dapat bekerja efektif;

(xi) Penggunaan cara lain yang memungkinkan; di antaranya menggunakan metabolit sekunder yang diekstraksi medium yang ditumbuhi jamur agen biokontrol dan setelah diencerkan diaplikasikan misalya melalui penyemprotan. Cara mirip ini pernah sukses diuji dalam mengendalikan antraknosa pada cabe merah di lapagan [83]; 
aplikasi senyawa bioaktif bakteri agen biokntrol mampu mengendalikan peyakit kresek padi (rice bacterial leaf blight) yang disebabkan oleh $X$. orizae [84].

Cara aplikasi pestisida untuk pengendalian penyakit tanaman dilakukan dengan beberapa cara yaitu:

(i) Cara sebar yaitu pemberian pestisida agar merata keseluruh areal, misalnya dengan spraying, blowering, fogging (pengasapan), serta aplikasi melalui pesawat terbang;

(ii) Membenamkan kedalam tanah atau menempatkan pestisida, biasanya dalam bentuk granular;

(iii) Cara penyuntikan, yaitu aplikasi pestisida yang biasanya dilakukan dengan cara menggunakan alat aplikasi yang memungkinkan bahan aktif pestisida masuk ke dalam tanah (sekitar perakaran) untuk tujuan melindungi perakaran dari serangan patogen tular tanah (soil borne patogen);

(iv) Cara infuse, yaitu aplikasi pestisida yang dilakukan bertujuan memasukkan bahan aktif pestisida ke dalam jaringan tanaman dengan alat bantu statis. 


\subsection{Pengelolaan Pascapanen dan Penyimpanan}

Penyimpanan merupakan salah satu tahap penting karena pada periode tersebut bahan mengalami proses penurunan kualitas dan kuantitas. Untuk menjaga kualitas, pemerintah telah menetapkan standar mutu (gabah) dan melakukan pengawasan terhadap pengolahan, pengangkutan dan sarana penyimpanan agar kualitasnya dapat dipertahankan dan tingkat kerusakan dapat ditekan, sehingga nilai ekonomi tetap tinggi.

Kualitas produk hasil panen dipengaruhi oleh kualitas awal, rentang waktu simpan, teknik atau metode penyimpanan dan kondisi gudang.

Khusus untuk beras, setelah dipanen padi disimpan dalam bentuk gabah dan/atau beras. Penyimpanan diperlukan karena: (i) padi dipanen secara musiman, sementara beras dibutuhkan setiap hari, dan (ii) padi sebagai stok pangan untuk mengatasi masa-masa sulit, seperti terjadinya kekeringan dan banjir yang mengakibatkan gagal panen, (iii) gabah yang disimpn dengan baik untuk mendapatkan harga yang lebih baik di kemudian hari.

Di penyimpanan, produk hasil pertanian selalu dijumpai adalah serangan hama gudang dan pathogen. Di Asia Tenggara yang beriklim tropis dan lembab, kerusakan pasca panen padi 30\% (5-15\% disebabkan hama gudang). Di Amerika Serikat yang fasilitas 
penyimpanannya modern, kerugian oleh hama gudang 5 M dolar AS/tahun. Di negara berkembang yang fasilitas penyimpan banyak yang bersifat tradisional, maka kerusakan diprediksi lebih besar lagi.

Pada gabah dan beras yang disimpan dengan cara yang tidak bak sering dijumpai munculnya bau apek, tumbunya miselia jamur, saling melekat atau bergumpal, bahkan sampai berkecambah. Kondisi ini bukan hanya membuat nilai produk menjadi jatuh tetapi juga menurunkan kepercayaan konsumen. Sudah biasa kita ketahui dari media massa, Negara-negara di Eropa, Amerika Serikat, dan berbagai Negara pengimport komoditas dari Negara berkembang menolak produk karena terkontaminasi atau terinfestasi organisme termasuk pathogen saprofitik perusak bahan.

Di Indonesia penyimpanan gabah dilakukan oleh petani, pedagang dan Bulog dengan karaketristik yang berbeda-beda.

Proses dimulai dari panen yang dilakukan oleh petani; kemudian disimpan gabahnya secara sederhana dengan jumlah terbatas untuk kebutuhan pangan keluarga sendiri. Oleh petani gabah dimasukkan ke karung plastik ukuran 50-75 kg setelah dikeringkan sampai kadar air $12 \%$. Selanjutnya diletakkan di salah satu tempat dalam rumah yang difungsikan sebagai gudang. Sebagian gabah hasil panen dengan bantuan jasa dikonversi menjadi beras; tahap berikutnya beras 
dibeli oleh pedagang dan/atau Bulog. Saat panen raya, pedagang membeli gabah petani, mengeringkan dan menyimpannya sesuai dengan kemampuan modal dan gudang yang dimiliki. Gudang umumnya berupa bangunan yang difungsikan sebagai tempat menyimpan gabah, belum memiliki struktur dan fasilitas modern.

Bulog sebagai institusi yang diberi mandat oleh Negara untuk menyimpan gabah dan atau beras secara besar-besaran, mengingat: (i) diperlukannya jaminan penyediaan pangan nasional, (ii) gabah atau beras disimpan di gudang yang dirancang khusus dan dilengkapi dengan fasilitas penyimpanan modern.

Dari aspek kajian penyakit yang hampir seluruhya disebabkan oleh mikroorganisme penyebab kerusakan, maka dalam kajian Ilmu Gudang, maka perhatian ditujukan pada aktivitas dua kelompok besar mikroorganisme yaitu: jamur dan bakteri. Beberapa genus jamur yang paling sering menginfestasi bahan simpanan di antaranya adalah: Aspergillus, Penicillium, Mucor, Rhizopus, dan Actinomycetes.

Jamur dapat menjadi penyebab rusaknya bahan yang ditandai dengan tumbuhnya jamur di bahan simpanan, karena:

(i) Kelembaban udara yang tinggi; kelembaban udara yang tinggi akan memfasilitas peningkatan aktivitas biolog jamur di permukaan dan di dalam bahan di penympnanan; 
(ii) Kadar air bahan relatif tinggi; biji-bijian termasuk padi dan jagung misalnya diupayakan tidak melebihi $12 \%$ kadar airnya. Kadar air yang tinggi meunjukkan ketersediaan air yang tinggi di dalam bahan yang sesuai bagi aktivitas biologi pathogen di permukaan dan dalam bahan;

(iii) Konstruksi dan kondisi fisik gudang. Konstruksi tempat penyimpanan akan mempengaruhi kelancaran sirkulasi udara. Gudag tanpa ventilasi akan membahayakan keutuhan bahan simpanan. Dalam kondisi ini biasanya kelembaban meningkat yang mendorong respirasi bahan dan makin meningkatkan kadar air bahan, sehingga makin kndusif bagi aktivitas biolog jamur dan bakteri saprofitik.

Pada kasus seragan jamur saprofitik pada gabah dan beras adalah: terjaidnya perubahan warna babah berubah warna, timbul bau tidak sedap, penurunan daya tumbuh benih dan beras menjadi tidak layak dikonsumsi. Hal yang serupa terjadi pula pada berbagai komditas biji-bijian lainnya. Di samping itu spora jamur menyebabkan alergi jika terhirup manusia. Aspergillus flavus menghasilkan aflatoksin yang beracun dan karsinogenik bagi manusia. Sementara itu Fusarium sp menghasilkan seralinon yang berbahaya. 
Pengendalian terpadu bagi mikroorganisme perusak bahan di penyimpanan yang efektif adalah dengan komponen terdiri atas:

1. Pemeliharaan konstruksi bangunan penyimpanan. Sirkulasi udara dalam gudang penyimpanan yang berfungsi baik, maka suhu dan kelembaban udara tidak sesuai untuk pertumbuhan jamur. Untuk bangunan yang belum berdiri, maka dalam perencanaan harus mempertimbangkan ketersediaan system ventilasi baik dalam bentuk jendela yang dilengkapi dengan screen dan/atau dilengkapi dengan alat sirkulasi udara yang biasanya ditempatkan di bagian atap. Bila bangunan lama, maka perlu dipastikan apakah system sirkulasi udara sudah tersedi dan dalam kondisi baik atau belum. Renovasi bangunan perlu dilakukan jika bangunan belum dilegkapi dengan komponen struktur yang bisa menjamin sirkulasi udra yang biak.

2. Memastikan kadar air bahan simpanan sebelum disimpan haruslah tidak lebih dari 12\%; makin rendah kadar air makin baik;

3. Untuk bahan-bahan tertntu memerlukan ruang berpendingin $\left(10^{\circ} \mathrm{C}\right.$ atau kurang) setelah bahan (misalnya padi) dikemas;

4. Menjaga sanitasi gudang dan membuatnya tetap kering meskipun musim hujan. Sanitasi harus 
dijamin di bagian dalam bangunan dan tumpukan bahan harus bersih. Hal ini harus menjadi perhatian. $70 \%$ hama yang menginfestasi penyimpanan padi misalnya berada di permukaan kemasan, $17 \%$ mencapai bagian tengah kemasan, dan 13\% hidup hingga bagian paling dalam. Berbagai hama juga bisa sebagai vector jamur dan bakteri perusak.

5. Mengeleminasi sumber infestasi dan distribusi organisme pengganggu mengingat organisme termasuk jamur dalam bentuk spora dapat tersebar melalui pergerakan udara dan terdesposisi di celahcelah sempit pada dinding, peralatan dan pintu, atau masuk setelah merusak kemasan pembungkus.

6. Pemantauan dan pendeteksian terhadap bahan simpanan dan lingkunganya di dalam bangunan serta terhadap konstruksi luar bangunan dan lingkungan luar gudang. Kegiatan ini bertujuan untuk mengetahui secara pasti jenis organisme perusak, statusnya (hama-patogen atau sekedar pengganggu dan belum merugikan), sumber infestasi, kemungkinan tempat masuk dan sebagai dasar untuk menyusun tindakan lebih lanjut seperti sanitasi dan eradikasi. Pengamatan dilakukan dengan pengambilan contoh (Gambar x) dan pemerangkapan hama. Pengambilan sampel, 
penarikan contoh secara sistematik dan mewakili seluruh sampel dilakukan dengan tangan atau alat bantu.

7. Aplikasi pestisida kimia sintetis dalam bentuk:

(i) Penyeprotan pada bagaian dalam bangunan termasuk dinding dan lantai di mana biasa terdapat celah termasuk kayu tatakan tumpukan barang yang biasanya didiami serangga. Menekan populasi serangga berarti menekan vector jamur dan pathogen kontaminan. Penyemprotan bisa dilakukan pada bagian luar bangunan yang dapat menjadi sumber inokulum.

(ii) Fumigasi, yaitu aplikasi gas beracum (fumigant pada fase uap/gas) ntuk membunuh serangga termasuk vector jamur dan bakteri kontaminan dan perusak bahan simpanan. Satu0satunya fumigant yang beredar di Indonesia adalah phosphin yang diformulasi dalam bentuk tablet padat berdiameter 2-3 cm dengan ketebalan kurang dari satu $\mathrm{cm}$. Dosis yang digunakan antara 13 tablet per $\mathrm{m}^{3}$ ruangan. 


\section{Pertanyaan Bab 7}

1. Apa yang dimaksud dengan memanipulasi lingkungan dalam konteks pegelolaanpenyakit tanaman;

2. Apa yang dimasud dengan fumigasi dalam pengelolaan organisme kontminan di gudang?

3. Jelaskan bagaimana pengelolaan gudang yang baik untuk mecegah berkembangnya jamur dan bakteri perusak bahan makanan;

4. Anda adalah manajer perkebunan, diminta untuk menangani penyakit pada kelapa sawit yang disebabkan oleh pembusuk busuk pangkal batang. Jelaskan persiapan dan tindakan pengelolaan penyakitnya yang bisa menjamin sukses. 


\section{DAFTAR PUSTAKA}

[1] Tilman D, Cassman KG, Matson PA, Naylor R \& Polasky S. 2002. Agricultural sustainability and intensive production practices. Nature 418, 671677.

[2] Sutarman. 2017. Dasar-dasar ilmu peyakit tanaman. UMSIDA Presss. 2017.

[3] Lu Y, Rao S, Huang F, Cai Y, Wang G, \& Cai K. 2016. Effects of biochar amendment on tomato bacterial wilt resistance and soil microbial amount and activity. Int. J. Agron. 2016: 2938282.

[4] Helina S, Sulandari S, Hartono S, Trisyono A. 2018. Detection and transmission of rice stunt virus on Ciherang and Situ Bagendit varieties. J. HPT Tropika. 18(2): 169-176. DOI: 10.23960/J.Hptt.218169-176.

[5] Iswanto EH, Munawar D, \& Rahmini. 2020. Resistance evaluation of modern rice varieties to brown planthopper Nilaparvata lugens STÅL. J. HPT Tropika. 20(2):157-164. DOI : 10.23960/J.Hptt.220157-164.

[6] Swibawa IG, Susilo FX, Purnomo, Aeny TN, Utomo SD, \& Yuliadi E. 2020. Infestation of major pests and diseases on various cassava clones in Lampung-Indonesia. J. HPT Tropika. 20(1):13-18. DOI: $10.23960 /$ J.Hptt.12013-18.

[7] Sutarman. 2017. Pengendalian Penyakit Benih dan Bibit. UMSIDA Press.

[8] Sutarman. Hadi S, Saefuddin A, Achmad, Suryani A. 2004. Epidemiologi hawar daun bibit Pinus merkusii yang disebabkan oleh Pestalotia theae. Jurnal Manajemen Hutan Tropika 10 (1): 43-60.

[9] Febbiyanti TR, Wiyono S, Yahya S, \& Widodo. 2019. Analysis of causative factors for stem canker 
disease epidemic on rubber plants in South Sumatra. J. HPT Tropika. 19(1): 82-91 DOI : 10.23960/J.Hptt.11982-91.

[10] Suharti T, Joko T, \& Arwiyanto T. 2017. Deteksi bakteri patogen terbawa benih akor (Acacia auriculiformis a. cunn. ex benth.). J. HPT Tropika. 17(1): $19-36$.

[11] Sutarman \& Prihatiningrum AE. 2015. Penyakit hawar daun Pinus merkusii di berbagai persemaian kawasan utama hutan pinus Jawa Timur. J. HPT Tropika. 15(1): $44-52$.

[12] Glare T, Caradus J, Gelernter W, Jackson T, Keyhani N, Kohl J, Marrone P, Morin L \& Stewart A. 2012. Have biopesticides come of age? Trends Biotechnol. 30, 250-258.

[13] Buysens C, César V, Ferrais F, De Boulois HD \& Declerck S. 2016. Inoculation of Medicago sativa cover crop with Rhizophagus irregularis and Trichoderma harzianum increases the yield of subsequently-grown potato under low nutrient conditions. Applied Soil Ecology 105,137-143.

[14] Pruksakorn P, Arai M, Kotoku N, Vilchèze C, Baughn AD, Moodley P, Jacobs WR Jr, \& Kobayashi M. 2010. Trichoderins, novel aminolipopeptides from a marine sponge-derived Trichoderma sp., are active against dormant mycobacteria. Bioorg. Bioorganic Med. Chem. Lett. 20(12): 3658-3663.

[15] Yedidiaa I, Benhamoub N, Kapulnikc Y \& Cheta I. 2000. Induction and accumulation of PR proteins activityduring early stages of root colonizationby the mycoparasite Trichoderma harzianum strain T-203. Plant Physiology and Biochemistry 38 (11): 863-873.

[16] Chowdappa P, Kumar SPM, Lakshmi MJ, \& Upreti KK. 2013. Growth stimulation and induction of systemic resistance in tomato against early and late blight by Bacillus subtilis OTPB 1 or Trichoderma harzianum OTPB3. Biol. Control. 65(1): 109-117. 
[17] Hu X, Roberts DP, Xie L, Maul JE, Yu C, Li Y, Zhang Y, Qin L \& Liao X. 2015. Components of a riceoilseed rape production system augmented with Trichoderma sp. Tri-1 control Sclerotinia sclerotiorum on oilseed rape. Phytopathology 105, 1325-1333.

[18] Martínez-Medina, A., Pascual, J.A., Perez-Alfocea, L.F., Roldán, A., 2010. Trichodermaharzianum and Glomus intraradices modify the hormone disruption induced by Fusarium oxysporum infection in melon plants. Phytopathology 100, 682-688.

[19] Vinale F, Sivasithamparam K, Ghisalberti EL, Marra RS, Woo L \& Lorito M. 2008. Trichoderma-plantpathogen interactions. Soil Biol. Biochem. 40, 1-10.

[20] Hu X, Roberts DP, Xie L, Yu C, Li Y, Qin L, Hu L, Zhang Y, \& Liao X. 2016. Use of formulated Trichoderma sp. Tri-1 in combination with reduced rates of chemical pesticide for control of Sclerotinia sclerotiorium on oilseed rape. Crop Prot. 79: 124127.

[21] Tasik S, Widyastuti SM, \& Harjono. 2015. Mekanisme parasitisme Trichoderma harzianum terhadap Fusarium oxysporum pada semai Acacia mangium. J. HPT Tropika. 15(1): $72-80$.

[22] Sutarman. 2019. Application of Trichoderma harzianum as soil treatment and additional treatment for control of potato diseases. J. Agric. Sci. 2(2): 139-150.

[23] Huang J, Wei Z, Tan S, Mei X, Yin S, Shen Q, \& Xu Y. 2013. The rhizosphere soil of diseased tomato plants as a source for novel microorganisms to control bacterial wilt. Appl. Soil Ecol. 72: 79- 84.

[24] Sutarman. 2016. Seleksi Trichoderma Spp Dari Bawah Tegakan Pinus Dan Uji Daya Dukung Isolat Terpilih Terhadap Pertumbuhan Tomat Dan Sawi. Hlm. 125-134 dalam Prosiding Konser Karya Ilmiah Nasional; Salatiga, 4 Agustus 2016. Prihtanti 
TM dan Herawati MM (peny,), Salatiga, Indonesia, Universitas Kristen Satya Wacana, Salatiga.

[25] Ginting C, Prasetyo J, Nurhidayat A, \& Maryono T. 2017. Efikasi isolat Trichoderma terpilih dengan bahan organik untuk mengendalikan penyakit busuk pangkal batang pada lada di lapangan. $J$. HPT Tropika. 17(1): $77-83$.

[26] Jahuddin R, Jamila, Awaluddin, \& Suriani. 2018. Exploration and screening for endophytic microbes of maize plant root against Fusarium verticillioides. J. HPT Tropika. 18(1): 57-64. DOI : 10.23960/J.Hptt.11857-64.

[27] Prihatiningsih N \& Djatmiko HA. 2016. Enzim amilase sebagai komponen antagonis Bacillus subtilis b315 terhadap Ralstonia solanacearum kentang. J. HPT Tropika. 16(1): $10-16$.

[28] Kim HJ, Choi HS, Yang SY, Kim IS, Yamaguchi T, Sohng JK, Park SK, Kim JC, Lee CH \& Garderner BM. 2014. Both extracellular chitinase and new cyclic lipopeptide,chromobactomycin, contribute to the biocontrol activity of Chromobacterium sp. C61. Molecular Plant Pathology 15(2): 122-132

[29] Raza, W., Yousaf, S., and Rajer, F. U. (2016). Plant growth promoting activity of volatile organic compounds produced by biocontrol strains. Sci. Lett. 4, 40-43.

[30] Tahir, H. A. S., Gu, Q., Wu, H., Niu, Y., Huo, R., and Gao, X. 2017. Bacillus volatiles adversely affect the physiology and ultra-structure of Ralstonia solanacearum and induce systemic resistance in tobacco against bacterial wilt. Sci. Rep. 7:40481. doi: $10.1038 /$ srep40481

[31] Ortíz-Castro, R., Contreras-Cornejo, H. A., MacíasRodríguez, L., and López-Bucio, J. (2014). The role of microbial signals in plant growth and development. Plant Signal. Behav. 4, 701-712. doi: $10.4161 /$ psb.4.8.9047 
[32] Batoo T, Ali S, Seleiman MF, Naveed NM, Ali A, Ahmed K, Abid M, Rizwan M, Shahid MR, Alotaibi M, Al-Ashkar I \& Mubushar M . Plant growth promoting rhizobacteria alleviates drought stress in potato in response to suppressive oxidative stress and antioxidant enzymes activities. Scientifc Reports. (2020) 10: 16975 .

https://doi.org/10.1038/s41598-020-73489-Z

[48]

[33] Radchenko VV, Vasilyev IY, Ilnitskaya EV, Garkovenko AV, Asaturova AM, Tomashevich NS, Kozitsyn AE, Milovanov AV, Grigoreva TV, Shternshis MV. 2020. Draft genome sequence of the plant growth- promoting bacterium Bacillus subtilis strain BZR 517, isolated from winter wheat, now reclassified as Bacillus velezensis strain BZR 517. Microbiol Resour Announc 9:e00853-20. https://doi.org/10.1128/MRA.00853-20.

[34] Hafiz A. S. Tahir, Qin Gu, Huijun Wu, Waseem Raza, Alwina Hanif, Liming Wu, Massawe V. Colman and Xuewen Gao. Plant Growth Promotion by Volatile Organic Compounds Produced by Bacillus subtilis SYST2. Front. Microbiol., 2017. https://doi.org/10.3389/fmicb.2017.00171.

[35] ]Blake, C., Nordgaard Christensen, M., \& Kovács, Á. T. (2020). Molecular aspects of plant growth promotion and protection by Bacillus subtilis. Molecular Plant-Microbe Interactions ${ }^{\circledR}$. doi:10.1094/mpmi-08-20-0225-cr

[36] Chen XH, Koumoutsi A, Scholz R, Eisenreich A, Schneider K, Heinemeyer I, Morgenstern B, Voss B, Hess WR, Reva O, Junge H, Voigt B, Jungblut PR, Vater J, Süssmuth R, Liesegang H, Strittmatter A, Gottschalk G, Borriss R. 2007. Comparative analysis of the complete genome sequence of the plant growth-promoting bacterium Bacillus amyloliquefaciens FZB42. Nat Biotechnol 25:10071014. https://doi.org/10.1038/nbt1325. 
[37] Borriss R, Danchin A, Harwood CR, Médigue C, Rocha EPC, Sekowska A, Vallenet D. 2018. Bacillus subtilis, the model Gram-positive bacterium: 20 years of annotation refinement. Microb Biotechnol 11:3-17. https://doi .org/10.1111/17517915.13043.

[38] Zakia A, Ilyas S, Budiman C, Syamsuddin, \& Manohara D. 2018. Exploration and selection of rhizobacteria that inhibit Phytophthora capsici in vitro. J. HPT Tropika. 18(1): 83-94. DOI : 10.23960/J.Hptt.21883-94.

[39] Gil VS, Pastor S and GJ March Quantitative isolation of biocontrol agents Trichoderma spp., Gliocladium spp. and actinomycetes from soil with culture media. Microbiol. Res. 2009;164(2):196-205

[40] Li Y, Feng J, Liu H, Wang L, Hsiang T, Li X, \& Huang J. 2016. Genetic diversity and pathogenicity of Ralstonia solanacearum causing tobacco bacterial wilt in China. Plant Dis. 100(7): 12881296.

[41] Wuryandari Y, Wiyatiningsih S, \& Maroeto. 2015. Formula berbahan aktif Pseudomonad fluoresen dan pengaruhnya terhadap perkembangan penyakit layu pada cabai. J. HPT Tropika. 15(1): 89 - 94.

[42] Yanti Y, Habazar T, \& Resti Z. 2017. Formulasi padat rhizobakteria indigenus Bacillus thuringiensis TS2 dan waktu penyimpanan untuk mengendalikan penyakit pustul bakteri Xanthomonas axonopodis pv. glycines. J. HPT Tropika. 17(1): $9-18$.

[43] Muis A, Djaenuddin N, \& Nonci N. 2015. Evaluasi lima jenis inner carrier dan formulasi Bacillus subtilis untuk pengendalian hawar pelepah jagung (Rhizoctonia solani kuhn). J. HPT Tropika. 15(2): $164-169$.

[44] Gusnawaty HS, Taufik M, Bande LOS, \& Asis A. Efektivitas beberapa media untuk perbanyakan 
agens hayati Trichoderma sp. J. HPT Tropika. 17(1): $70-76$.

[45] John NS, Anjanadevi IP, Nath VS, Sankar SA, Jeeva ML, John KS, \& Misra RS. 2015. Characterization of Trichoderma isolates against Sclerotium rolfsii, the collar rot pathogen of Amorphophallus - A polyphasic approach. Biological Control, 90, 164172.doi:10.1016/j.biocontrol.2015.07.001.

[46] Youssef SA, Tartoura KA \& Abdelraouf GA. 2016. Evaluation of Trichoderma harzianum and Serratia proteamaculans effect on disease suppression, stimulation of ROS-scavenging enzymes and improving tomato growth infected by Rhizoctonia solani. Biological Control 100, 79-86.

[47] Saravanakumar K, Yu C, Dou K, Wang M, Li Y, \& Chen J. 2016. Synergistic effect of Trichodermaderived antifungal metabolites and cell wall degrading enzymes on enhanced biocontrol of Fusarium oxysporum f. sp. cucumerinum. Biol. Control. 94: 37-46.

[48] Chowdappa P, Kumar SPM, Lakshmi MJ, \& Upreti KK. 2013. Growth stimulation and induction of systemic resistance in tomato against early and late blight by Bacillus subtilis OTPB1 or Trichoderma harzianum OTPB3. Biol. Control 65(1): 109-117.

[49] Nurbailis, Martinius, \& Naipinta R. 2017. Kesintasan beberapa jamur antagonis pada buah cabai dan potensinya dalam menekan penyakit antraknosa yang disebabkan oleh Co lletotrichum gloeosporioides. J. HPT Tropika. 17(2): 162-169.

150] Hutauruk D, Suryanto D, \& Munir E. 2016. Asai isolat bakteri kitinolitik Bacillus sp. BK17 pada media pembawa tanah gambut dan kompos janjang kelapa sawit dalam menghambat pertumbuhan jamur patogen Sclerotium rolfsii dan Fusarium oxysporum pada kecambah cabai. J. HPT Tropika. 16(1): $61-70$. 
[51] Sutarman. 2017. Pengujian Trichoderma sp. sebagai pengendali hawar daun bibit kakao yang disebabkan oleh Phytophthora palmivora. J. HPT Tropika. 17(1): $45-52$.

[52] Tahir HAS, Gu Q, Wu H, Niu Y, Huo R, \& Gao X. 2017. Bacillus volatiles adversely affect the physiology and ultra-structure of Ralstonia solanacearum and induce systemic resistance in tobacco against bacterial wilt. Sci. Rep. 7: 40481.

[53] Subiadi, Sipi S, \& Basundari FRA. 2019. Decrease in production and quality of grain due to neck blast disease in some lowland rice varieties. J. HPT Tropika 19(1): 74 - 81. DOI : 10.23960/J.Hptt.11975-82.

[54] Suryantini R \& Soelistijono. 2020. Development of pink disease on various ages of Acacia crassicarpa cunn ex. benth. J. HPT Tropika. 20(2): 116-122. DOI : 10.23960/J.Hptt.220116-122

[55] Wicaksono D, Wibowo A, \& Widiastuti A. 2017. Metode isolasi Pyricularia oryzae penyebab penyakit blas padi. J. HPT Tropika. 17(1): 62 - 69.

[56] Saridewi LP, Prihatiningsih N, \& Djatmiko HA. 2020. Characterization of eggplant endophyte bacteria and rhizobacteria as well as their antagonistic ability against Ralstonia solanacearum. J. HPT Tropika. 20(2): 150-156. DOI : 10.23960/J.Hptt.220150-156

[57] Kumar S, Stecher G, Li M, Knyaz C, \& Tamura K. 2018. MEGA X: Molecular evolutionary genetics analysis across computing platforms. Mol. Biol. Evol. 35(6): 1547-1549.

[58] [NCBI] National Center for Biotechnology Infromation. 2020. Basic Logical Alignment Search Tool. $\quad$ http://www.ncbi.nlm.nih.gov/BLAST. Diakses 23 Maret 2020.

[59] Kurniawati F, Suastika G, \& Giyanto. 2015. Identifikasi Tomato Infectious Chlorosis Virus penyebab penyakit klorosis pada tanaman tomat di 
Cipanas Jawa Barat melalui perunutan nukleotida gen protein selubung utama. J. HPT Tropika. 15(1): $33-43$.

[60] Fierer N, Jackson JA, Vilgalys R, \& Jackson RB. 2005. Assessment of soil microbial community structure by use of taxon-specific quantitative PCR assays. Appl. \& Environ. Microb. 71(7): 4117-4120.

[61] Supyani, Dwiwiyati Nurul Septariani, \& Hadiwiyono. 2020. Symptoms variation of viral infectionsin yardlong bean. J. HPT Tropika. 20(1): 28-36. DOI : 10.23960/J.Hptt.12028-36

[62] Prasetyo AE, Mutaqin KH, \& Giyanto. 2017. Karakterisasi fitoplasma penyebab penyakit layu kelapa di pulau derawan menggunakan rflp in silico J. HPT Tropika. 17(2): $105-110$.

[63] Miftakhurohmah, Suastika G, Damayanti TA, \& NoverizaR. 2015. Identifikasi molekuler Broad Bean Wilt Virus 2 (BBWV2) dan Cymbidium Mosaic Virus (CyMMV) asal tanaman nilam (Pogostemon cablin benth.). J. HPT Tropika. 15(2): 188 - 199.

[64] Melinda, Damayanti TA, \& Hidayat SH. 2015. Identifikasi molekuler Bean Common Mosaic Virus yang berasosiasi dengan penyakit mosaik kuning kacang panjang. J. HPT Tropika. 15(2): $132-140$.

[65] Yanti Y, Hamid H, \& Reflin. 2018. Indigenous rhizobacteria screening from tomato to control Ralstonia syzigii subsp. Indonesiensis and promote plant growth rate and yield. J. HPT Tropika. 18(2): 177-185. DOI : 10.23960/J.Hptt.218177-185.

[66] Sa'diyah N, Adawiah, Prasojo I, Rugayah, Dirmawati SR. Genotypic selection on red chili plants resistant to anthracnose disease at $\mathrm{M} 2$ generation. J. HPT Tropika. 18(2): 151-159. DOI: 10.23960/J.Hptt.218151-159.

[67] Evizal R, Sugiatno, Ivayani, Pujisiswanto H, Wibowo L, \& Prasmatiwi FE. 2018. Incidence dynamic of 
pod rot disease of cocoa clones in Lampung, Indonesia . J. HPT Tropika. 18(2): 105-111.

[68] Ginting S, Nadrawati, Zarkani A, \& Sumarni T. 2020. Natural incidence of entomopathogenic fungus Nomuraea rileyi on Spodoptera frugiperda infesting corn in Bengkulu. J. HPT Tropika. 20(2): 85-91. DOI : 10.23960/J.Hptt.22085-91

[69] Dweba, C. C., Figlan, S., Shimelis, H. A., Motaung, T. E., Sydenham, S., Mwadzingeni, L., \& Tsilo, T. J. (2017). Fusarium head blight of wheat: Pathogenesis and control strategies. Crop Protection, 91, 114122.doi:10.1016/j.cropro.2016.10.002.

[70] Djaenuddin N \& Muis A. 2017. Efektivitas biopestisida Bacillus subtilis Bnt 8 dan pestisida nabati untuk pengendalian penyakit hawar pelepah dan upih daun jagung. J. HPT Tropika. 17(1): 53 61.

[71] Djaenuddin N, Muis, \& Nurnina Nonci. 2018. Screen house test of eight biopesticide formulation Bacillus subtilis against downy mildew, Peronosclerospora Philipinensis, on corn plant. J. HPT Tropika. 18(1): 51-56. DOI : 10.23960/J.Hptt.11851-56

[72] Khairan, Aulina, Bahi M, Eriana CN, \& Sriwati R. 2019. Fungicidal activity of garlic (Allium sativum) bulbs extracts against plants pathogenic fungi. J. HPT Tropika. 19(1): 23-32. DOI : 10.23960/J.Hptt.11923-32.

[73] Wuryandari Y, Wiyatiningsih S, \& Maroeto. 2017. Introduksi formula pupuk hayati berbahan aktif Pseudomonad fluorescent isolat PF-122 untuk meningkatkan pertumbuhan dan produksi tanaman cabai di lapang. J. HPT Tropika. 17(1): $156-161$.

[74] Singh A, Shukla N, Kabadwal BC, Tewari AK, \& Kumar J. 2018. Review on plant-Trichodermapathogen interaction. Int.J.Curr.Microbiol. App.Sci. 
$7(2)$ :

Doi:

https://doi.org/10.20546/ijcmas.2018.702.291.

[75] Sumartini. 2016. Efikasi campuran minyak cengkeh dan ekstrak biji mimba untuk pengendalian penyakit karat (Phakopsora pachyrhizi) pada kedelai (Glycine max). J. HPT Tropika. 16(1): $82-89$.

[76] Karuppiah V, Sun J, Li T, Vallikkannu M, \& Chen J. 2019. Co-cultivation of Trichoderma asperellum GDFS1009 and Bacillus amyloliquefaciens 1841 causes differential gene expression and improvement in the wheat growth and biocontrol activity. Frontiers in Microbiology, 10.

[77] Hewedy OA, Abdel Lateif KS, Seleiman MF, Shami A, Albarakaty FM, \& El-Meihy MR. 2020. Phylogenetic diversity of Trichoderma strains and their antagonistic potential against soil-borne pathogens under stress conditions. Biology 9(8), 189.

[78] Anam GB, Reddy MS, \& Ahn YH. 2019. Characterization of Trichoderma asperellum RM-28 for its sodic/saline-alkali tolerance and plant growth promoting activities to alleviate toxicity of red mud. Sci. Total Environ. 662: 462-469.

[79] Shang J, Liu B, \& Xu Z. 2020. Efficacy of Trichoderma asperellum TC01 against anthracnose and growth promotion of Camellia sinensis seedlings. Biol. Control. 143: 104205.

[80] Alimudin, Syamsiah M, \& Raamli . 2017 Aplikasi pemberian ekstrak bawang merah (Allium cepa L.) terhadap pertumbuhan akar stek batang bawah mawar (Rosa sp.) varietas malltic. J. Agroscience. 17(1): $194-202$.

[81] Putri MM \& Damayanti TA. 2020. Utilization of plant extracts to suppress Squash Mosaic Virus infection on ridged gourd (Luffa acutangula [L.Roxb]). J. HPT Tropika. 20(2): 108-115 . DOI : 10.23960/J.Hptt.220108-115. 
[82] Hayati I, Wiyono S, Widodo, \& Sobir. 2019. Organic fertilizer amendments reduce disease severity of Phytophthora palmivora root rot of duku (Lansium domesticum) seedlings. J. HPT Tropika. 19(2): 143148. DOI : 10.23960/J.Hptt.219143-148.

[83] Soesanto L, Mugiastuti E, Suyanto A, \& Rahayuniati RF. 2020. Application of raw secondary metabolites from two isolates of Trichoderma harzianum against anthracnose on red chili pepper in the field. J. HPT Tropika. 20(1): 19-27. DOI : 10.23960/J.Hptt.12019-27.

[84] Kurniawati S, Mutaqin KH, \& Giyanto. 2015. Eksplorasi dan uji senyawa bioaktif bakteri agensia hayati untuk pengendalian penyakit kresek pada padi. J. HPT Tropika. 15 (2): $170-179$. 
